Article

\title{
Research Trends in Geotourism: A Bibliometric Analysis Using the Scopus Database
}

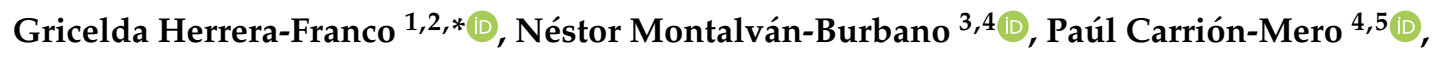 \\ Boris Apolo-Masache ${ }^{4,5}$ and María Jaya-Montalvo $6, *$ (i) \\ 1 Universidad Estatal Península de Santa Elena (UPSE), Facultad de Ciencias de la Ingeniería, \\ Avda. principal La Libertad-Santa Elena, La Libertad 240204, Ecuador \\ 2 ESPOL Polytechnic University, Geo-Recursos y Aplicaciones GIGA, Campus Gustavo Galindo Km 30.5 Vía \\ Perimetral, Guayaquil P.O. Box 09-01-5863, Ecuador \\ 3 University of Almería, Management and Business Department, Ctra. Sacramento s/n, La Cañada de San Urbano, \\ 04120 Almería, Spain; nmb218@inlumine.ual.es \\ 4 ESPOL Polytechnic University, Centro de Investigaciones y Proyectos Aplicados a las Ciencias de la \\ Tierra (CIPAT), Campus Gustavo Galindo Km 30.5 Vía Perimetral, Guayaquil P.O. Box 09-01-5863, Ecuador; \\ pcarrion@espol.edu.ec (P.C.-M.); bhapolo@espol.edu.ec (B.A.-M.) \\ 5 ESPOL Polytechnic University, Facultad de Ingeniería en Ciencias de la Tierra, Campus Gustavo Galindo \\ Km 30.5 Vía Perimetral, Guayaquil P.O. Box 09-01-5863, Ecuador \\ 6 Bira Bienes Raíces S.A. (BIRA S.A.), Barrio La Y Av. Alonso de Mercadillo, Zar uma 071350, Ecuador \\ * Correspondence: grisherrera@upse.edu.ec (G.H.-F.); mjaya@espol.edu.ec (M.J.-M.); \\ Tel.: +593-99-261-3241 (G.H.-F.); +593-98-250-9363 (M.J.-M.)
}

Received: 27 August 2020; Accepted: 16 September 2020; Published: 23 September 2020

\begin{abstract}
Geodiversity has elements of exceptional scientific value that are considered to represent geoheritage, or geological heritage. One way to conserve and promote the knowledge of these elements is through the initiatives of United Nations Educational, Scientific, and Cultural Organization (UNESCO) Global Geoparks, which, over a decade ago, began to notably highlight a new sustainable tourism alternative called geotourism, or geological tourism, that promotes the protection of the unique geological resources of territory and, at the same time, provides social, economic, and environmental benefits. This study aims to investigate the scientific information related to geotourism in the Scopus database through a bibliometric analysis, using the VOSviewer software, for the evaluation of the structure, conceptual evolution, and trends of geotourism following related publications. The research comprises four study phases: (i) search criteria of the research field; (ii) search and selection of documents; (iii) software and data extraction; and (iv) analysis of results and trends. The results present geotourism as a scientific discipline that is in a phase of exponential research growth and exhibits its scientific productivity from 1984 to 2019, where three main periods are differentiated: introduction, theoretical development, and diversification of information. The most active research area is geomorphological heritage, which is very far from the emerging line of research of engineering geology in geotourism. However, growing exploration during the last six years has generated the development of various geoscientific branches promoted by geotourism that, currently, present their research area trends such as geosites, geoheritages, and geoparks.
\end{abstract}

Keywords: geotourism; geoheritage; bibliometric analysis; cocitation; co-occurrence; VOSviewer; Scopus

\section{Introduction}

Planet Earth holds unique places that are outstanding samples of geological evolution and can be attractive elements for tourism. The range of unique geological features that are products of the history of the Earth, and that man can currently appreciate in various forms (rocks, minerals, fossils, 
soil), are peculiarities that bring together a very diverse landscape system known as geodiversity [1,2]. Geodiversity is a topic that emerged in 1993 shortly after the Convention on Biological Diversity (CBD), which promulgated the agreement for the protection of biodiversity the sustainable use of its elements and genetic resources. The spread of biodiversity sparked the interest of geoscientists who, later in the 1990s, proposed the term "geodiversity" that would become increasingly used around the world, even being recognised by the International Union for Conservation of Nature (IUCN) [3,4]. There are numerous examples of geodiversity singularity or geological destinations of international relevance (e.g., Pedra-que-Pica, the largest fossiliferous coquina of the approximately 20,000 known ocean-volcanic islands in the world [5], Wieliczka Salt Mine, sites subjected to the World Heritage Convention in Poland [6], diamond mines of the Yimengshan Geopark (China) [7], and the Monumental Quarry Remains [8]). Visible to the naked eye, these arouse scientific, educational, and tourist interest [9], promoting socioeconomic development [10] and sociocultural sustainability [11].

Within geodiversity, the abiotic elements of the natural heritage are identified, which are established as the product of various actions due to nature and high relevance. There are structures or elements of the past of great value that still prevail today. These sites (even created by human activity) are called geoheritage, or geological heritage, which have significant social, historical, and cultural value that deserves rescued, conserved, and implemented restructuring systems for adequate geoconservation towards sites that have a unique element of geodiversity [3,12].

The framework of geodiversity, geoconservation, and being able to rescue various unique characteristics of a site make geotourism or geological tourism a form of sustainable tourism, focused on promoting and conserving geological heritage or sites with unique geological features of a territory (geosites) [13]. Geosites consider sites with a high value of geological interest, which are valued quantitatively and qualitatively through an audit, evaluation, and selection process to develop a management and threat prevention plan for their respective management and conservation [14]. The term geotourism with a modern approach was first proposed in 1995 by Hose, who defined it as a form of tourism based on the understanding and acquisition of geological knowledge at a given site, beyond a superficial and straightforward view of the sector $[13,15,16]$. However, it was not until 2001 that the alternative vision of geotourism from a geographic tourism approach appeared publicly in the National Geographic Society (NGS) and Travel Industry Association of America (TIA) [17], where it officially disclosed the term geotourism, contributing to its popularisation.

Over time, the term geotourism has focused more on the context of geographic tourism. In 2011 at the International Congress on Geotourism held in Arouca (Portugal), the concept of geotourism was clarified, adding "geology" to the definition of geotourism as "tourism which sustains and enhances the identity of a territory, taking into consideration its geology, environment, culture, aesthetics, heritage, and the well-being of its residents." Additionally, tourism can be viewed as one of the multiple components of geotourism when considered in its broadest terms $[13,18]$.

Based on Hose's concept of geotourism with a geological focus [15], various definitions of geotourism emerged [19-32]. These definitions exposed different approaches to geotourism such as those by Larwood and Prosser [19], who associate it with an experience to travel, learn, enjoy, and, at the same time, promote Earth's heritage conservation, or by Hose, who redefines geotourism as the promotion of geosites for its geointerpretation, either inside (urban) or outside (rural) the site, to guarantee its protection and conservation to appreciate, enjoy, educate, and research [32]. Despite the different approaches and evolution of geotourism, since the mid-90s, the common denominator is the themes of geoconservation and geointerpretation, which are fundamental elements for its conceptualisation.

Currently, a globally accepted definition is proposed by Newsome and Dowling [21]: "Geotourism is a form of natural area tourism that specifically focuses on geology and landscape. It promotes tourism to geosites and the conservation of geodiversity and an understanding of earth sciences through appreciation and learning. This is achieved through independent visits to geological features, 
use of geotrails and viewpoints, guided tours, geoactivities, and patronage of geosite visitor centres". Figure 1 shows the evolution over time of the main definitions proposed for geotourism.

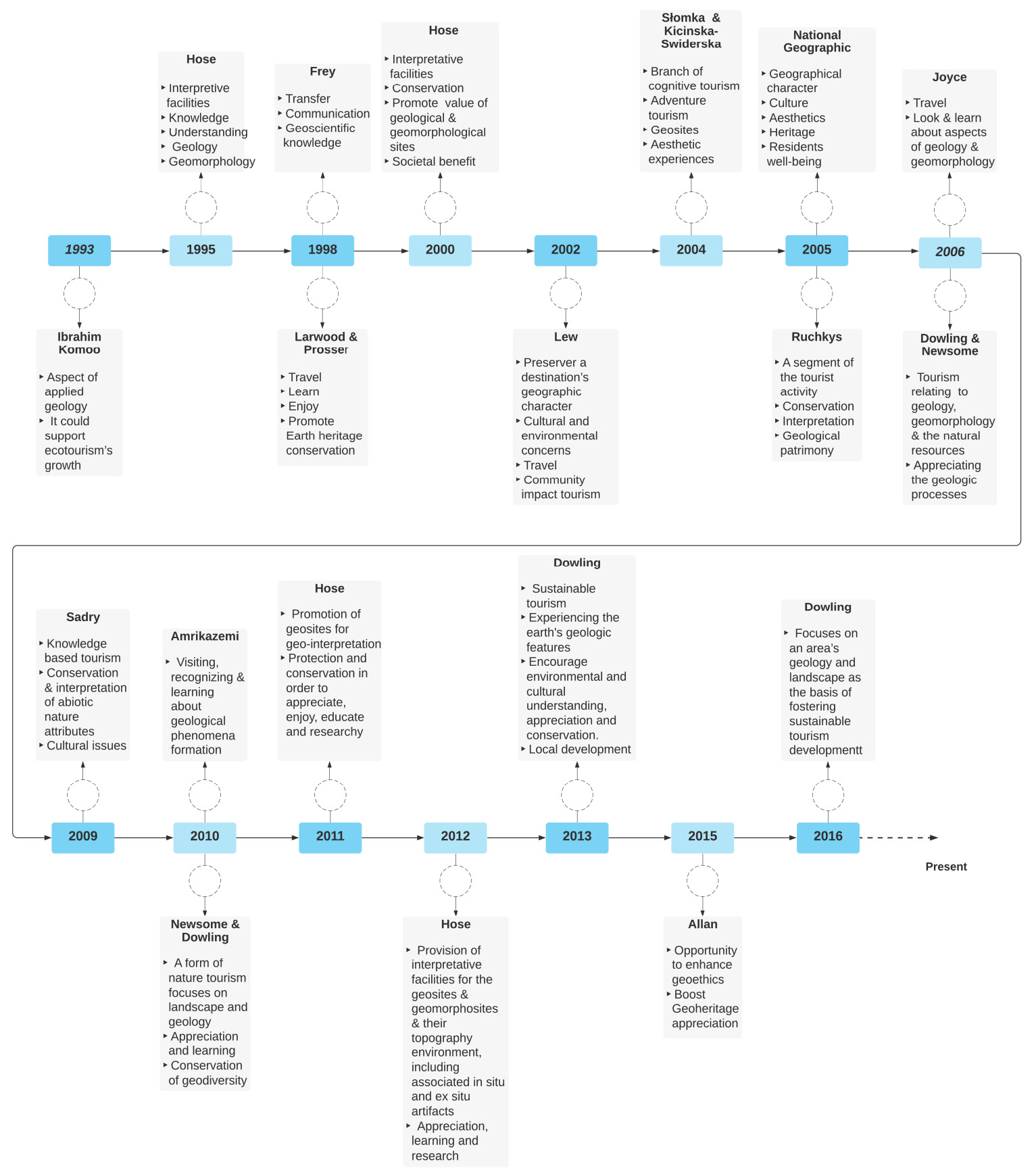

Figure 1. Timeline diagram showing the evolution of the definition of geotourism over time.

Geotourism has excellent potential for a wide variety of actions, such as the geopark initiative and its economic sustainability [33,34], creating geotrails or georoutes [35], and the evaluation and heritage conservation (cultural, geological, and mining $[13,28,36,37]$ ) of geosites as a tool for geoeducation $[2,38,39]$. Some examples of forms of geotourism are underground geotourism [40,41], geotourism in volcanic and geothermal environments [42], geomorphological heritage [43], geotourism in natural areas such as Crystal Cave in the Yanchep National Park of Western Australia [44] or The Ichnite Route of Soria in Spain [35], as well as in urban areas like the Hong Kong Geopark in China [45], Old Centre of São Paulo City in Brazil [46], and three Urban Geosites in Mexico City [47]. 
For the recognition of landscapes for singular characteristics, geotourism has been implemented in different areas of knowledge, with an increase in the search for a reference or model of geotourism typology $[45,48,49]$. Geotourism must comply with five fundamental principles such as (i) those geologically based (geoheritage), (ii) sustainable (geoconservation), (iii) educational (geointerpretation), (iv) with benefits at the local level, and (v) with tourist satisfaction, the first three principles being directly linked to geotourism.

The implementation of these characteristics differentiates geotourism from other forms of tourism, where the human being coexists with nature and its environments, such as ecotourism (focused on flora and fauna), cultural tourism (geomitology, rock art, and cultural value in vestiges and other geological elements of society), and adventure tourism (an activity that encourages exploration and connection with nature through extreme sports) [48].

One of the initiatives that promotes and conserves places that enjoy unique geological and landscape riches are the so-called geoparks, where geotourism is an integral and essential part of their development [48,49]. According to the United Nations Educational, Scientific, and Cultural Organization (UNESCO), geoparks are geographic areas in which highly recognised sites of geological interest or geosites that possess a unique landscape stand out. Geotourism seeks to preserve sustainable and beneficial development for local communities, in addition to the protection or geoconservation of its geological, natural, and cultural heritage. In turn, to be included in its Global Geopark Network, a network that, until 2020, comprised 147 geoparks, around 41 countries have achieved this official recognition [50].

Given the importance of geotourism, studies related to bibliometric and bibliographic analyses are presented. Table 1 highlights the theoretical framework and literature reviews of geotourism: "A New Form of Tourism Utilising Natural Landscapes and Based on Imagination and Emotion" [51], a literature review, and the responses from the electronic questionnaires sent to geoparks around the world [10]; the importance, English origin, and evolution of the term geotourism by Hose [32]; a geographical review of literature on geotourism published between 2012 and 2014 in an online database "Scopus "of Ruban [52]; the handbook of Dowling and Newsome [53], which brings together much of the latest concerns and information on geotourism as it has developed over the past two decades; the research of [54,55]; del Río-Rama et al., [56], tourism in islands, where it places Dowling and Newsome [57] among the authors who address the new tourism trends; the bibliometric analysis of Ibáñez, Brevik, and Cerdà [58]; and a systematic literature review (SLR) of geotourism and territorial development [59]. 
Table 1. Geoscientific contribution around geotourism (studies related to the subject that use bibliometric and bibliographic analyses [10,32,51-59]).

\begin{tabular}{|c|c|c|c|c|c|c|}
\hline Authors & Year & Title & Scientific Contribution & Type of Study & Database & $\begin{array}{l}\text { Search } \\
\text { Period }\end{array}$ \\
\hline Pralong, J. P. & 2006 & $\begin{array}{l}\text { Geotourism: A New Form of } \\
\text { Tourism Utilising Natural } \\
\text { Landscapes and Based on } \\
\text { Imagination and Emotion }\end{array}$ & $\begin{array}{l}\text { Definition and demand } \\
\text { trends of geotourism }\end{array}$ & $\begin{array}{l}\text { Theoretical framework and } \\
\text { literature review of } \\
\text { geotourism }\end{array}$ & & \\
\hline $\begin{array}{l}\text { Farsani, N. T., Coelho, C., } \\
\text { and Costa, C. }\end{array}$ & 2011 & $\begin{array}{l}\text { Geotourism and Geoparks as } \\
\text { Novel Strategies for } \\
\text { Socioeconomic Development in } \\
\text { Rural Areas }\end{array}$ & $\begin{array}{c}\text { Geopark and geotourism } \\
\text { literature review and its role } \\
\text { in the development of rural } \\
\text { economies }\end{array}$ & $\begin{array}{l}\text { Literature review and the } \\
\text { responses from the } \\
\text { electronic questionnaires } \\
\text { sent to geoparks around the } \\
\text { world }\end{array}$ & & \\
\hline Hose, T. A. & 2011 & $\begin{array}{l}\text { The English Origins of } \\
\text { Geotourism (As a Vehicle for } \\
\text { Geoconservation) and their } \\
\text { Relevance to Current Studies }\end{array}$ & $\begin{array}{l}\text { Contextualises the } \\
\text { recognition of the geotourism } \\
\text { concept and propose a new } \\
\text { geotourism definition }\end{array}$ & Literature Review & & \\
\hline Ruban & 2015 & $\begin{array}{l}\text { Geotourism-A Geographical } \\
\text { Review of the Literature }\end{array}$ & $\begin{array}{l}\text { Geographical review of } \\
\text { literature on geotourism }\end{array}$ & Bibliographical survey & Scopus & 2012-2014 \\
\hline $\begin{array}{l}\text { Dowling, R., and } \\
\text { Newsome, D. }\end{array}$ & 2018 & Handbook of Geotourism & $\begin{array}{c}\text { Definitions, characteristics, } \\
\text { development, international } \\
\text { perspectives, and case } \\
\text { studies of Geotourism }\end{array}$ & Literature Review & & \\
\hline $\begin{array}{l}\text { Ólafsdóttir, R. and } \\
\text { Tverijonaite, E. }\end{array}$ & 2018 & $\begin{array}{l}\text { Geotourism: A Systematic } \\
\text { Literature Review }\end{array}$ & $\begin{array}{l}\text { Systematic literature review } \\
\text { (geotourism) }\end{array}$ & $\begin{array}{c}\text { Systematic Literature } \\
\text { Review }\end{array}$ & $\begin{array}{l}\text { Scopus, Web of Science y } \\
\text { Science Direct }\end{array}$ & 2012-2018 \\
\hline Ólafsdóttir, R. & 2019 & Geotourism & $\begin{array}{c}\text { The conceptual evolution of } \\
\text { geotourism }\end{array}$ & $\begin{array}{l}\text { Bibliographic review of a } \\
\text { special issue of Geosciences, } \\
\text { entitled "Geotourism". }\end{array}$ & MDPI platform & 2018 \\
\hline Ibáñez, Brevik and Cerdà & 2019 & $\begin{array}{l}\text { Geodiversity and Geoheritage: } \\
\text { Detecting Scientific and } \\
\text { Geographic Biases and Gaps } \\
\text { through a Bibliometric Study }\end{array}$ & $\begin{array}{l}\text { Bibliometric study } \\
\text { (geodiversity and } \\
\text { geoheritage) }\end{array}$ & $\begin{array}{c}\text { Bibliometric and } \\
\text { bibliographic analysis }\end{array}$ & $\begin{array}{c}\text { Journal "Geoheritage", } \\
\text { Scopus, Google Scholar, } \\
\text { and list of UNESCO Global } \\
\text { Geoparks }\end{array}$ & 1983-2016 \\
\hline $\begin{array}{c}\text { del Río-Rama, M. D. L. C., } \\
\text { Maldonado-Erazo, C. P., } \\
\text { Álvarez-García, J., } \\
\text { and Durán-Sánchez, A. }\end{array}$ & 2020 & $\begin{array}{l}\text { Cultural and Natural } \\
\text { Resources in Tourism Island: } \\
\text { Bibliometric Mapping }\end{array}$ & $\begin{array}{l}\text { Bibliometric mapping } \\
\text { (tourism island) }\end{array}$ & $\begin{array}{c}\text { Bibliometric and } \\
\text { bibliographic analysis }\end{array}$ & Scopus & 1985-2019 \\
\hline $\begin{array}{c}\text { Duarte, A., Braga, V., } \\
\text { Marques, C., and Sá, A. A. }\end{array}$ & 2020 & $\begin{array}{l}\text { Geotourism and Territorial } \\
\text { Development: A Systematic } \\
\text { Literature Review and } \\
\text { Research Agenda }\end{array}$ & $\begin{array}{l}\text { Systematic literature review } \\
\text { of geotourism and territorial } \\
\text { development and advances }\end{array}$ & $\begin{array}{l}\text { Systematic literature review } \\
\text { and bibliometric analysis }\end{array}$ & Scopus & 2007-2018 \\
\hline
\end{tabular}


Even though these studies have contributed to the research topic (Table 1), the existence of a work that integrates and complements several facets in the geotourism section, focusing on trends, behaviours, and various projections, including more than the analysis, is essential, as well as bibliometric, VOS mapping, and clustering techniques [60]. It is a tool that has received considerable attention from the indications of bibliometric research for its ability to visualise and analyse a wide variety of bibliometric networks, which helps to integrate knowledge and understand the evolution of a field of research.

Bibliometric analysis, exposed by de Solla Price [61], is a technique widely and explicitly used in the quantitative and qualitative evaluation of the characteristics, structure, relationships, patterns, and current and future trends of scientific disciplines [62-65]. Moreover, it is a technique that can be used for a multidisciplinary evaluation through citations, cocitations [66,67], coauthorship [68], co-occurrences [65], and bibliographic coupling [66,69] in achieving transparent and reliable results that guarantee a significant contribution to researchers investigating a topic of interest.

Geotourism, being an emerging scientific discipline that has gained space as a form of sustainable tourism, which promotes the protection and preservation of geological resources and their environment, is a field that has developed many scientific studies and become a topic of interest.

Is it possible that bibliometric analysis in the evolution of the concept of geotourism allows us to develop the current state and new associations, trends that project the development of this term?

Therefore, a bibliometric study of the scientific publications that are indexed in the Scopus database during the period from 1984 to 2019, using the VOSviewer software, is proposed for the evaluation of the structure, conceptual evolution, and presenting trends of geotourism.

\section{Materials and Methods}

Systematic literature reviews in research work are of high relevance for the researcher, delving into the intellectual field and developing research questions that provide an increase in the capacity for knowledge [70]. These systematic reviews have an explicit algorithm that allows the selection and evaluation of the literature through a transparent and reproducible procedure that allows knowing an area of knowledge [71,72]. Bibliometric studies contemplate a similar formal and rigorous procedure that guarantees the quality of the information used [73,74].

Bibliometric analysis considered a scientific field by showing a comprehensive map of the structure of knowledge, its evaluation, and measurement [65,75], focused on the bibliographic analysis of scientific publications that are compiled in a database [76]. An essential part of these analyses is the use of bibliometric maps that allow the study of cognitive structure in detail and its dynamics over time in a given academic field [77]. For this purpose, the VOSviewer software developed by Van Eck and Waltman [78], a tool that allows the construction and visualisation of bibliometric networks for the analysis of an intellectual group (clustering solutions), was used throughout the time of the investigation, using elements of scientific publications such as authors, journals, keywords, references, and other bibliographic characteristics $[67,78]$, obtaining information from the field of study related to its origins, development, and trends.

The procedure to follow to carry out the bibliometric analysis was structured in four study phases, as shown in Figure 2. 


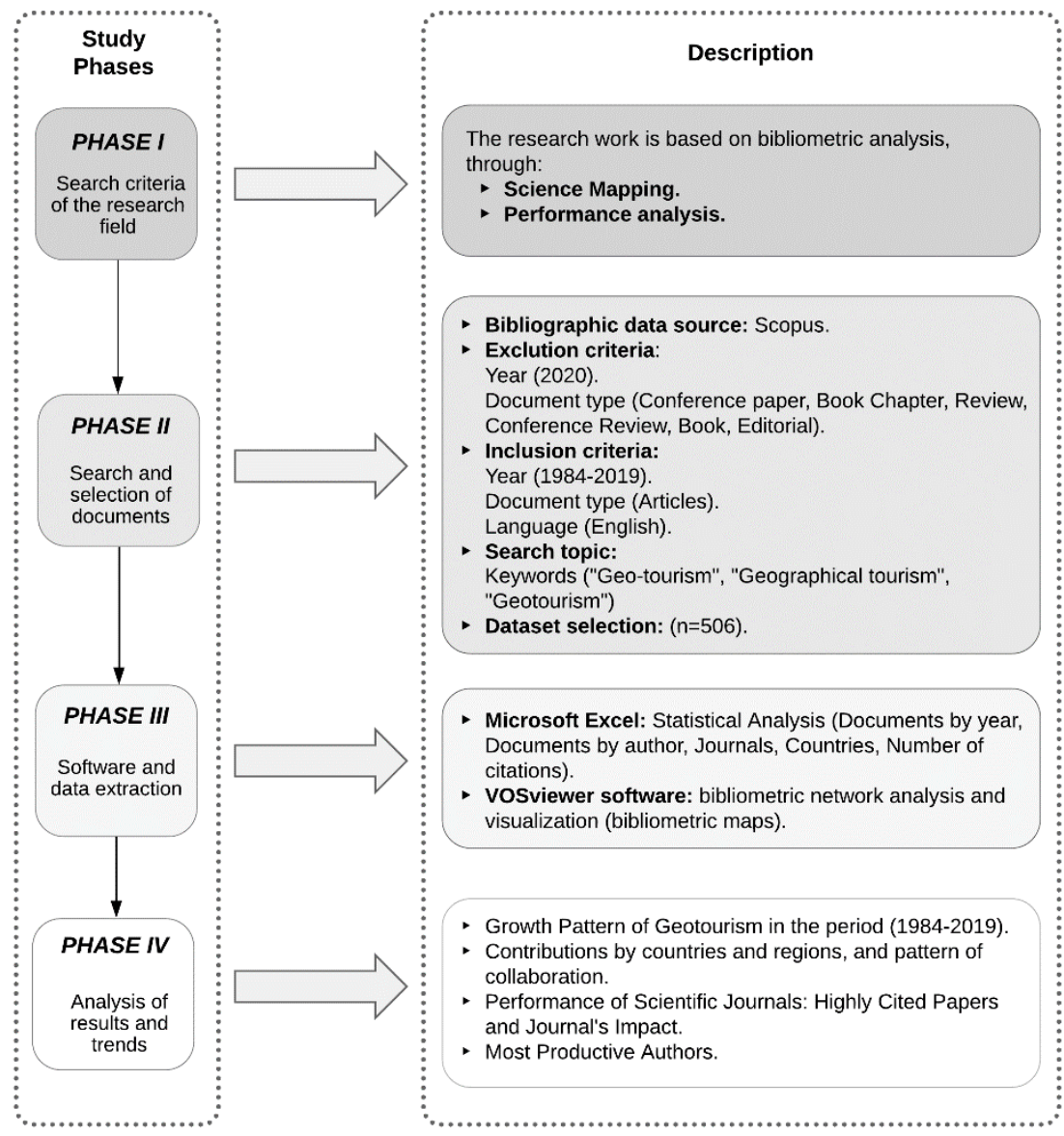

Figure 2. The developed method in this study.

\subsection{Phase I: Search Criteria of the Research Field}

The research work aims to evaluate the conceptual evolution of the research topic by combining two aspects in bibliometric analysis: (i) Performance Analysis and (ii) Science Mapping [76,79,80]. These aspects are commonly used to evaluate research performance and reveal the evolution, composition, intellectual structure, and dynamics that the field of research presents. [76,81].

Performance Analysis focuses on the essential characteristics of scientific publications, taking into account activity indicators such as the year of publication, number of documents, journals, countries, authors, universities, and other indicators of impact on scientific productivity such as the H-index in the journals $[56,67]$. At the same time, Science Mapping allows graphical representation of research fields and subfields by visualising and identifying relationships or links between them $[60,80]$.

\subsection{Phase II: Search and Selection of Documents}

The identification of the source or database must be of high quality and reliability for its bibliographic extraction. Therefore, following the methodological criteria of [56] in choosing the source, it was decided to carry out the study using the Scopus database, chosen mainly for its quality standards, broad coverage in the collection of information (Scopus currently has 1.7 billion cited references dating from 1970), ease in downloading data [82,83], and excellent coverage of geoscience journals [84].

The search and collection of information were carried out in the period 1984-2019. Beside, descriptors contained in titles, abstracts, and keywords related to the term geotourism, such as "geographical tourism" [85,86], "geotourism" [87], and "geotourism" [17]. Based on the chosen terms, 907 documents were obtained in the initial search, which went through a selection process by applying exclusion criteria in order to limit the search to document type (articles) and language (English). 
Only articles were included to assure the quality of the review, and this type of document goes through a rigorous pairwise review process. In this study, only articles in English were considered because English is the most widely used language in scientific publications [88]. Approximately $97-100 \%$ of documents in Google Scholar, are published in English (unique citations), and for unique citations, the percentage ranges from $62 \%$ to $80 \%$ (the Life Science and Earth Sciences area has $70 \%$ unique cited documents published in the English language). The second most frequent language is Chinese, according to Martín-Martín [89]. Additionally, no non-English geoscience journals were ranked within the top 50 Scimago rankings [90] and used as limitations in different bibliometric studies in geosciences [54,90-92].

Using Boolean logical operators, the following search was conducted. Search Topic: $\mathrm{ST}=$ (TITLE-ABS-KEY (“Geo-tourism") OR TITLE-ABS-KEY ("Geographical tourism”) OR TITLE-ABS-KEY ("Geotourism”)) AND (LIMIT-TO (DOCTYPE, “ar")) AND (EXCLUDE (PUBYEAR, 2020)) AND (LIMIT-TO (LANGUAGE, "English")). A total of 506 scientific documents obtained were used in the pre-established bibliometric analysis.

\subsection{Phase III: Software and Data Extraction}

The data collected were verified and examined based on their content or contribution to the research topic. Therefore, the bibliographic information of the 506 documents was downloaded in a comma-separated values (CSV) file, which is used in a wide variety of software focused on mapping analysis and scientific productivity. [79]. The original content that must be included in the download of this file consists of bibliographic data such as authors, title, year of publication, the title of the source, an affiliation of the authors, keywords, number, and data of the citations. This will later be published with great utility [81].

For the cleaning of extracted data, the CSV format was transferred to Microsoft Excel of Office 365 ProPlus for its revision, where it was verified if the bibliographic data coincided with the total number of scientific articles and that there was no necessary information missing as such as authors, year of publication, and other data mentioned in the extraction of Scopus. During the analysis, no aberrant data or missing information was found. Therefore, the work was carried out with the same amount of data established at the time of download: 506 scientific documents.

For the construction of the bibliometric mapping, the VOSviewer software was used for the ease of data processing, construction, and visualisation of bibliometric networks. [78,93]. The software has been used to study various scientific disciplines [56,65].

\subsection{Phase IV: Analysis of Results and Trends}

Data analysis consisted of two stages: the first focused on a statistical analysis of the metadata identified using Microsoft Excel of Office 365 ProPlus to obtain an analysis of productivity or annual growth trajectory, the performance of scientific journals, most cited documents, and the importance of the journal based on the impact factor or immediacy index (H-index) and SJR (SCImago Journal Rank) indicator.

In the second stage, the generation of bibliometric maps was established through the VOSviewer software, through which a technique was applied that included the analysis of author citations, coauthorship, and co-occurrence of the keywords of the authors. Documents were registered with a relationship or combination with each other. This way, the software was able to assign these words in similar groups, allowing clusters of various colours to be viewed and interconnected to analyse the resulting groupings subsequently [93].

\section{Results}

\subsection{Growth Pattern in Publications of Geotourism}

The analysis of scientific production was carried out using the content and number of publications presented per year, which allowed evaluating scientific literary evolution through bibliometric 
productivity indicators [94]. The bibliometric indicator known as Price's Law [95] was mainly used for productivity analysis in a particular discipline [94].

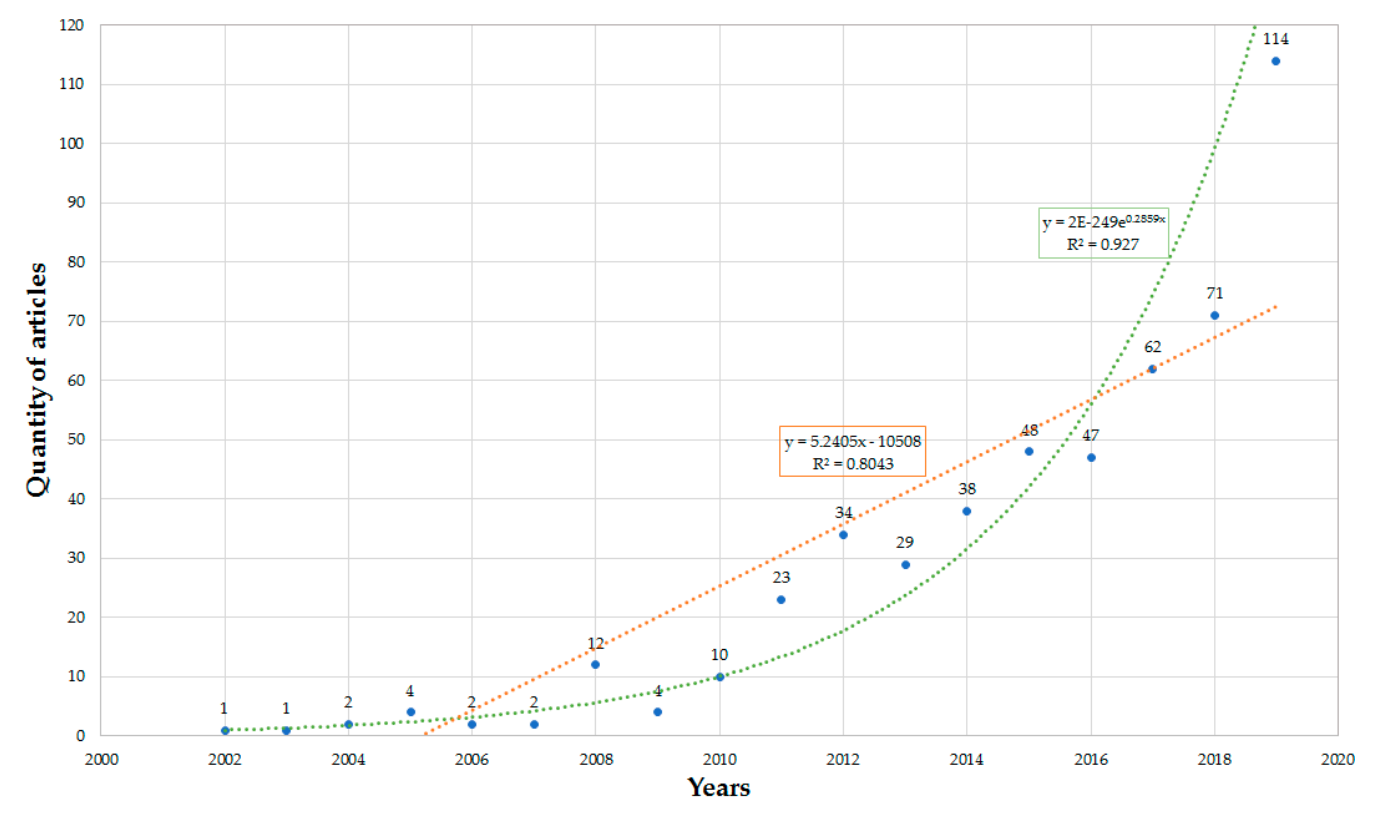

Figure 3. Annual growth trend.

To determine if the evolution of scientific productivity followed Price's exponential growth law, for practical purposes, we proceeded to evaluate the period 2002-2019 where more than $99.6 \%$ of articles were found. For effect, two types of regression models were evaluated, obtaining a linear equation of the type $y=5.2405 x-0508$ and an exponential equation of the type $y=2^{-249} \mathrm{e}^{0.2859 x}$ (Figure 3). Given the coefficient of determination $\left(R^{2}\right)$ of both equations, the value of the exponential productivity curve $\left(R^{2}=0.9270\right)$ was higher than the linear value $\left(R^{2}=0.8043\right)$, confirming that the research topic is in an exponential growth phase.

\subsection{Annual Production of Published Articles}

The scientific production obtained in the period of this research (Figure 4) presents an exponential growth of the articles published from 1984 to 2019. The development periods of geotourism research were identified based on the number of published articles and the appointments received, obtaining a total of three periods according to the behaviour of the curve.

Period I (1984-2005) exhibits the introduction to the topic of geotourism with a focus on the context of geographic tourism to increase tourism development and safeguard natural complexes $[85,86]$. In 2002, an article was published in which the term geotourism was officially presented and a definition was proposed that is associated with the concept of limited sustainable tourism, whose definition implicitly reveals geology [17].

Period II (2006-2012) is considered a stage of theoretical development and growth linked to the subject, with $17.15 \%$ of the total number of publications analysed, focusing on the importance of geotourism in areas with geological characteristics and an integral part of the UNESCO geoparks [48].

Finally, Period III is the diversification phase of geotourism research and owns $80.89 \%$ of all articles, given the results presented by Ruban, which consider geotourism as a growing scientific discipline that is addressed globally [52].

The considerations made in each period can validate the citations curve presented in Figure 4, thus having a significant number of citations that represent the elevated influence of the publications presented in consecutive years. 


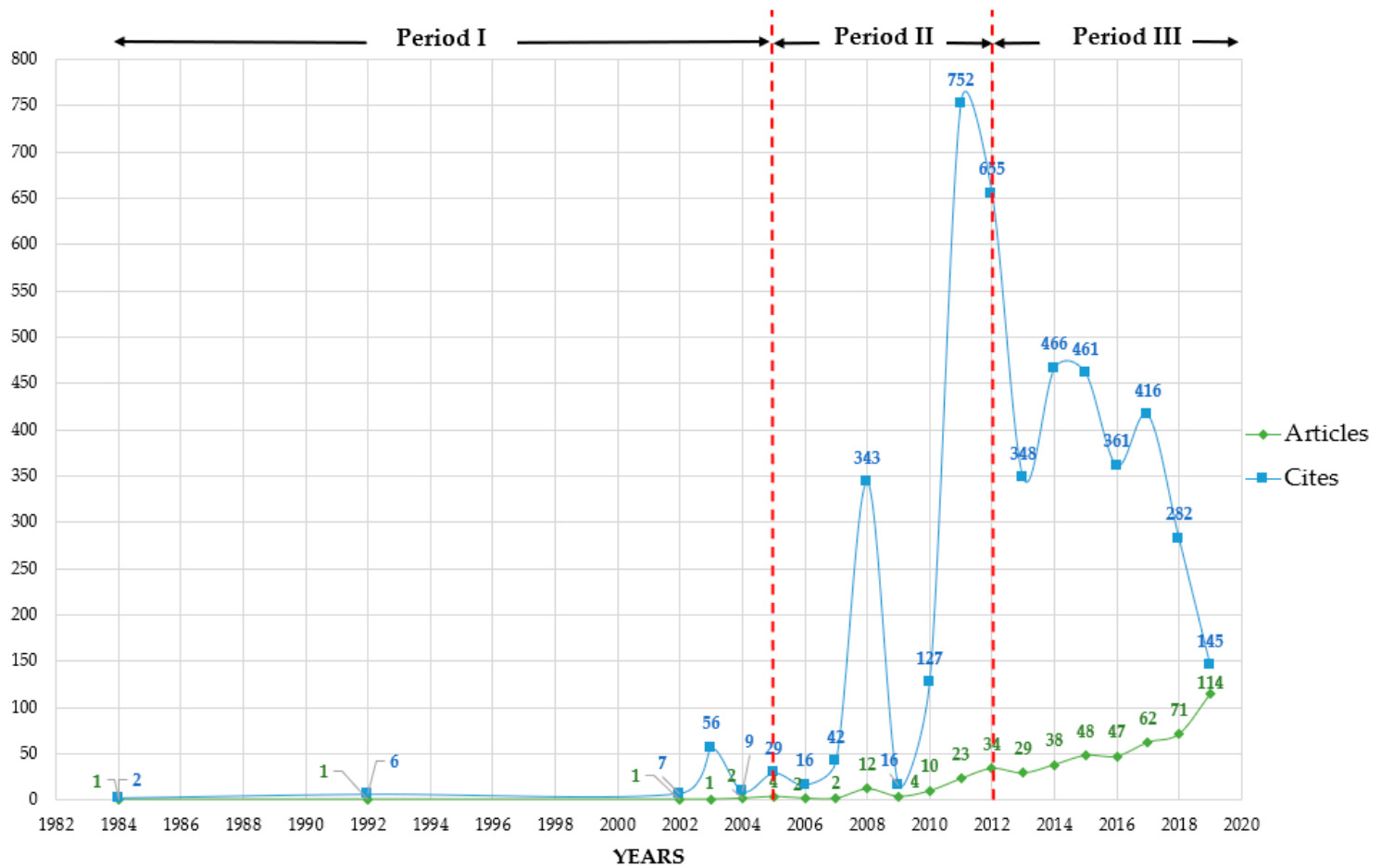

Figure 4. Scientific productivity charts from 1984 to 2019. Articles-Annual growth trajectory; cites-annual growth trajectory by cites.

\subsection{Top Cited Articles and Most Productive Authors}

Of the 506 scientific documents analysed, the following is shown (Table 2), the top 15 of the most cited articles in the established period, where the article "Geotourism's Global Growth" by Dowling tops the list with 158 citations.

In the proposed field of research, 1252 authors are presented. Figure 5 shows the top 15 most influential authors based on their occurrence given in the number of documents (Figure 5a) and several citations (Figure 5b) during the 1984-2019 period, showing a very different view from that in Table 2. According to the number of scientific documents (Figure 5a), Ruban leads the top 15 of the production with 23 documents, followed by Hose and Marković with 13 and 12 articles published, respectively. A very different approach is presented in Figure 5b, where Ruban appears fourth (227 citations) in the top 15 most productive authors according to the number of citations. Hose is the most cited author for geotourism with 530 citations.

(a)

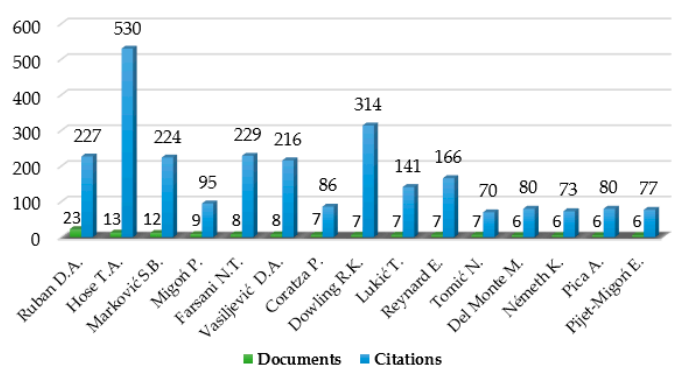

(b)

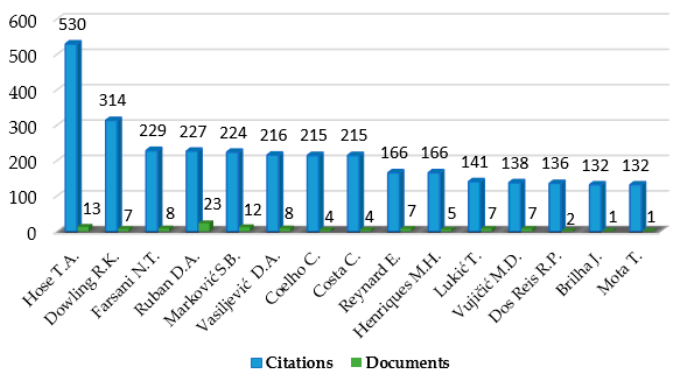

Figure 5. Performance graph of the top 15 most productive authors from 1984 to 2019. (a) Top 15 most productive authors by the number of documents; (b) top 15 most productive authors by the number of citations. 
Table 2. Top 15 most cited documents [1,10,22,43,48,52,96-104].

\begin{tabular}{|c|c|c|c|}
\hline Title & Authors & Journal & Citations \\
\hline Geotourism's Global Growth & Dowling, R. K. [48] & Geoheritage & 158 \\
\hline Geoconservation as an Emerging Geoscience & $\begin{array}{l}\text { Henriques, M. H., dos Reis, R. P., Brilha, J., } \\
\text { Mota, T. [101] }\end{array}$ & Geoheritage & 132 \\
\hline 3G's for Modern Geotourism & Hose, T. A. [102] & Geoheritage & 114 \\
\hline $\begin{array}{l}\text { Geotourism and Geoparks as Novel Strategies for } \\
\text { Socioeconomic Development in Rural Areas }\end{array}$ & Farsani, N. T., Coelho, C., Costa, C. [10] & $\begin{array}{l}\text { International Journal of Tourism } \\
\text { Research }\end{array}$ & 114 \\
\hline Geodiversity: Developing the Paradigm & Gray, M. [1] & $\begin{array}{l}\text { Proceedings of the Geologists' } \\
\text { Association }\end{array}$ & 91 \\
\hline $\begin{array}{c}\text { Towards a History of Geotourism: Definitions, Antecedents } \\
\text { and the Future }\end{array}$ & Hose, T. A. [103] & Geological Society Special Publication & 87 \\
\hline $\begin{array}{l}\text { The Nature and Management of Geotourism: A Case Study } \\
\text { of Two Established Iconic Geotourism Destinations }\end{array}$ & Newsome, D., Dowling, R., Leung, Y.-F. [104] & Tourism Management Perspectives & 77 \\
\hline $\begin{array}{l}\text { Rediscovering a Sense of Wonder: Geoheritage, Geotourism } \\
\text { and Cultural Landscape Experiences }\end{array}$ & Gordon, J. E. [96] & Geoheritage & 62 \\
\hline $\begin{array}{l}\text { Quantitative Assessment of Geotopes as an Effective Tool } \\
\text { for Geoheritage Management }\end{array}$ & $\begin{array}{c}\text { Fassoulas, C., Mouriki, D., Dimitriou-Nikolakis, P., } \\
\text { Iliopoulos, G. [97] }\end{array}$ & Geoheritage & 60 \\
\hline $\begin{array}{c}\text { Preliminary geosite assessment model (GAM) and its } \\
\text { application on fruška Gora mountain, potential geotourism } \\
\text { destination of Serbia }\end{array}$ & $\begin{array}{l}\text { Vujičić, M. D., Vasiljevićć, D. A., Marković, S. B., } \\
\text { Hose, T. A., Lukić, T., Hadžić, O., Janićević, S. [98] }\end{array}$ & Acta Geographica Slovenica & 59 \\
\hline $\begin{array}{l}\text { Scientific research and tourist promotion of } \\
\text { geomorphological heritage }\end{array}$ & Reynard, E. [43] & Geografia Fisica e Dinamica Quaternaria & 58 \\
\hline $\begin{array}{l}\text { Environmental inputs and outputs in ecotourism: } \\
\text { Geotourism with a positive triple bottom line? }\end{array}$ & Buckley, R. [99] & Journal of Ecotourism & 56 \\
\hline $\begin{array}{l}\text { Defining the Nature and Purpose of Modern Geotourism } \\
\text { with Particular Reference to the United Kingdom and } \\
\text { South-East Europe }\end{array}$ & Hose, T. A., Vasiljevićć, D. A. [22] & Geoheritage & 52 \\
\hline Geotourism-A geographical review of the literature & Ruban, D. A. [52] & Tourism Management Perspectives & 49 \\
\hline $\begin{array}{l}\text { Geo-knowledge Management and Geoconservation via } \\
\text { Geoparks and Geotourism }\end{array}$ & $\begin{array}{l}\text { Farsani, N. T., Coelho, C. O. A., Costa, C. M. M., } \\
\text { Amrikazemi, A. [100] }\end{array}$ & Geoheritage & 42 \\
\hline
\end{tabular}




\subsection{Contribution by Country and Region}

According to the affiliation obtained from each author in the database, the top 15 countries and regions that contributed the most in the world during 1984-2019 were identified based on two approaches: (i) number of documents published by country (Figure 6a) and (ii) number of citations per country (Figure 6b).
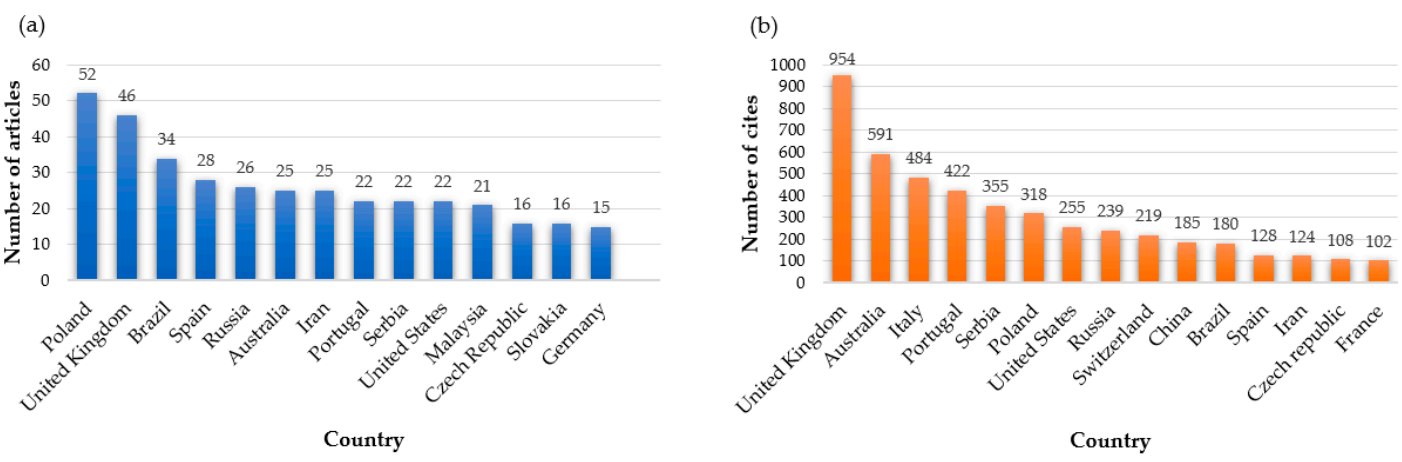

Figure 6. The top 15 most contributions and citations of articles by country from 1984 to 2019. (a) The number of articles by country published. (b) Total citations according to the country.

Figure 6a shows the 15 most contributing countries according to the number of articles published. Poland leads as the country with the highest number of documents, followed by the United Kingdom and Brazil with 46 and 34 articles, respectively. On the other hand, according to the number of citations (Figure 6b), the United Kingdom leads the order of the most contributing countries with a total of 954 citations, followed by Australia and Italy in the ranking of the best three.

\subsection{Productivity and Impact Analyses in Scientific Journals}

A total of 142 journals were analysed and evaluated in descending order according to the number of published documents. Table S1 shows the top 15 journals with the highest contribution representing $61.86 \%$ of the total articles. It shows the unique characteristics of each journal such as the number of articles, citations, the ranking of journals based on the evaluation by quartiles, the country of origin, the focus area and job category, and impact indicators such as the H-index and SJR 2018.

The "Geoheritage" journal has 165 articles, representing 32.61\% of the total (Table 2) and is the journal with the highest number of citations (1818 citations). The journal with the most significant impact determined by the H-index (Table S1) is the journal Quaternary International, which has a value of 93 and a contribution of six publications. The most relevant article in the journal with 31 citations is "The Introduction to Geoconservation of Loess-Paleosol Sequences in the Vojvodina Region: Significant Geoheritage of Serbia" [105]. This journal presents a methodology for geotouristic assessment and rescue of geosites with loess sediments in the Vojvodina-Serbia region.

The most significant number of journals focused on the Earth and Planetary Sciences area, with more than $50 \%$ of the publications focusing on the same area, highlighting the journal Geoheritage, which is positioned in the highest rank (both in terms of collaboration with the research field and the number of citations). This scientific journal focuses on characteristics of the world's geographic heritage and its protection, whose key topics cover aspects such as geoheritage management, geoparks, geotourism, sustainable development, education, and associated peculiarities [106].

\subsection{Network Visualisation}

\subsubsection{Co-Occurrence Analysis of Keywords}

In this section, an analysis of the bibliometric mapping of the three defined periods is carried out to obtain a result that shows the conceptual evolution of the established research topic through clusters 
that contain nodes of keywords that are related to each other (Figure 7). Table S2 provides the number of co-occurrences of keywords, links, and total link strength per cluster. Geotourism evolves from 5 to 59 co-occurrences in Period II and later reaches 245 with a connection strength (338) more significant than the other keywords.

Geotourism has been the centre of study within the analysed research field (Figure 7), including or supporting the increase in study areas such as geoheritage, geoparks, geosites, geoconservations, and geodiversity, which were initially part of the most prominent cluster, Cluster 1 (Figure $7 \mathrm{~b}$ ). Over time, they have developed their area, evolving into a broad field of study (Figure 7c) involving geotourism related to new issues and approaches. This is similar in Clusters 3, 4 and 5 (Figure 7c).

In Period I (1984-2005; Figure 7a), 28 keywords have at least one occurrence consisting of four clusters. Cluster 1 (red colour) focuses on indications of natural monuments, palaeontological heritage, and the creation of geoparks. The research topic "geotourism" focuses on the number of occurrences (referenced in the size of the node) and is intrinsically related to geomorphosites of all types of environments, and even deserts. They promote their geoconservation and education of geological regions. This case is similar to the topic area, which was somewhat far away, like Cluster 3 (aimed at geoconservation and education) albeit with stable connections.

In Period II (2006-2012; Figure 7b), a total of 223 keywords were found; however, only seven reached five occurrences, highlighting the formation of two closely related clusters among their nodes. Geotourism study dominates during this period (Cluster 1); thus, its development and redefinition based on its roots from the United Kingdom (the late 1990s) were examined [22,32]. There are links between geodiversity and the three essential aspects such as geointerpretation, geohistory, and geoconservation in order to achieve a sustainable management that protects geographical heritage and motivates people to seek new experiences to commemorate their travels $[96,102,104]$. Thus, they managed to register geosites, geoheritages, and geoparks through evaluations to validate and expose their geodiversity, uses, and interests that they present in order to generate adequate information on tourism management and disclosure for geotourism $[1,97,98,107-109]$.

Finally, Period III (2013-2019; Figure 7b) has 1152 keywords, of which only 33 reached five occurrences. These were distributed in eight clusters, leading Cluster 1, which shows an increasing interest in geoheritage, encouraging the recognition and evaluation of geomorphosites (patrimonies with geological and geomorphological interest) within an urban area [47,110,111]. The valuation, inventory, and development of nature or cultural heritage that each site presents was also promoted to increase geotourism interest and improve each place's management [112,113]. 
(a) Period I
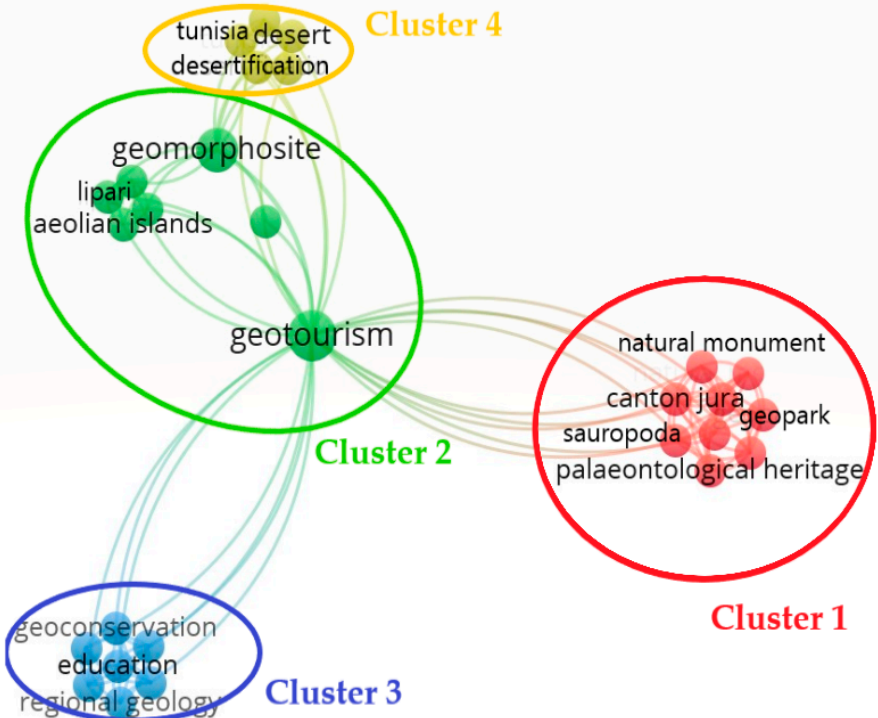

(b) Period II

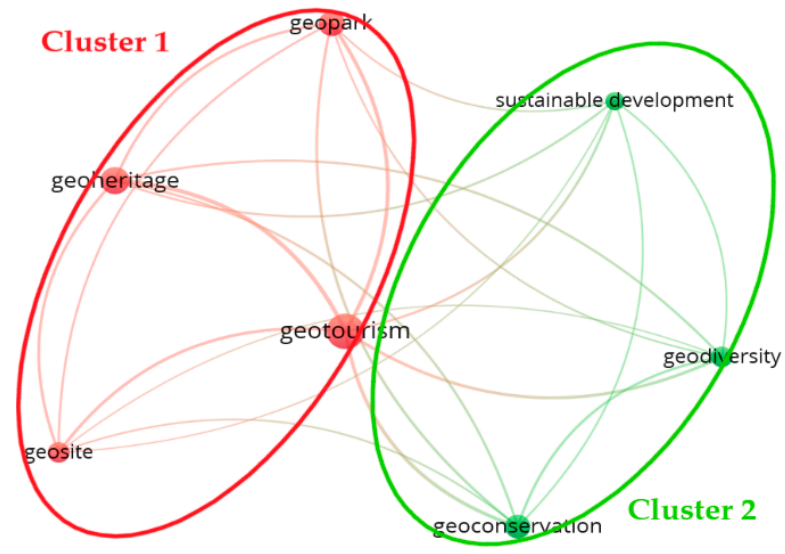

(c) Period III

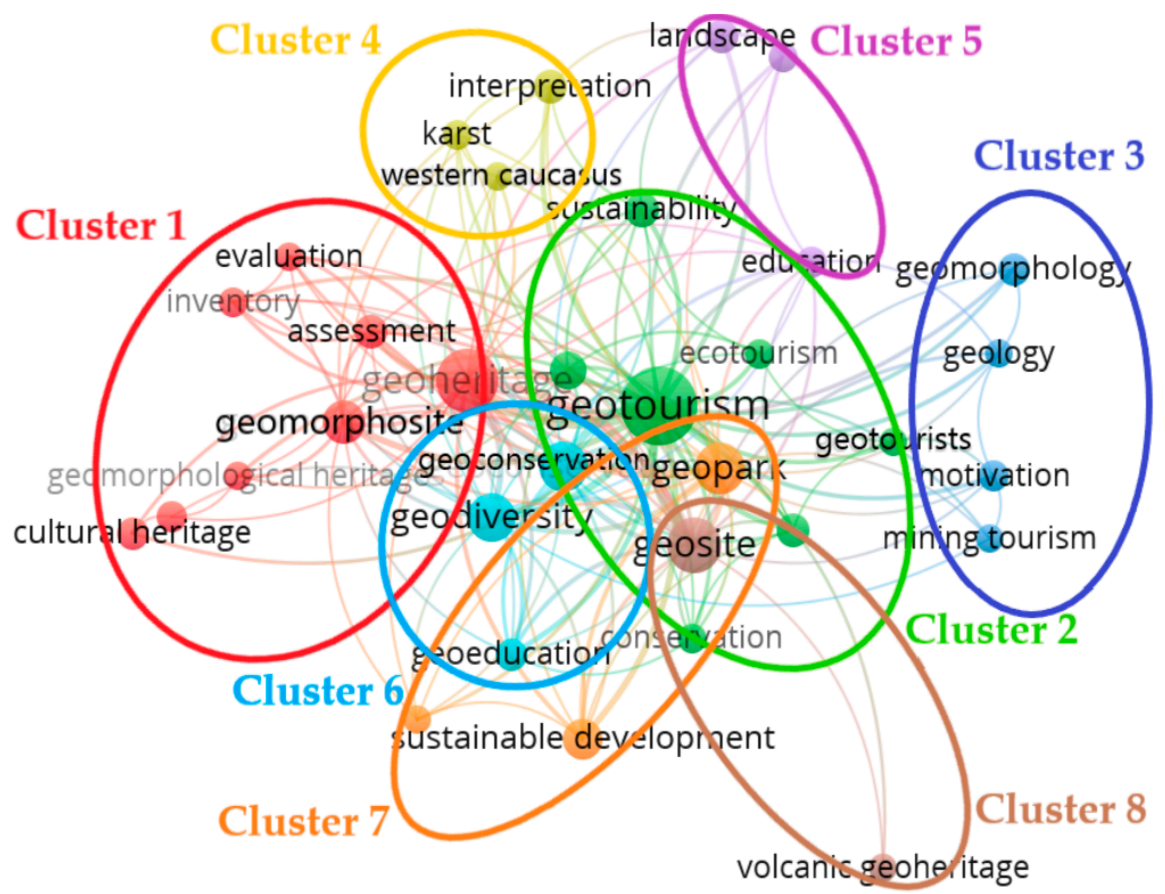

Figure 7. Map by periods of the evolution of geotourism. (a) Period I; (b) Period II; (c) Period III. 


\subsubsection{Author Cocitations Analysis}

To complement the results, the most productive authors, according to the number of citations (Figure 5b) and author cocitations analysis that appeared in the list of references were used to identify patterns in the number of articles written jointly by the authors on the theme. Cocitations analysis can identify the intellectual structure of a research field and answer matters regarding the field such as the primary research areas, most active areas, dissemination paths of the knowledge, and the emerging trend [114].

Once the references of the 506 scientific documents were processed, there were, in total, 22,922 cited authors. When applying the author filter with at least 20 citations, the sample was reduced to 240 authors who were cited 12,589 times. The 15 most cited authors are shown in Table 3.

Table 3. Top 15 authors cocited on 1984-2019.

\begin{tabular}{ccccc}
\hline Number & Authors & Cocitations & Links & Total Link Strength \\
\hline 1 & Hose, T. A. & 704 & 233 & 588.3852 \\
2 & Dowling, R. K. & 529 & 236 & 472.3633 \\
3 & Reynard, E. & 441 & 229 & 408.2449 \\
4 & Newsome, D. & 353 & 230 & 327.1631 \\
5 & Brilha, J. & 278 & 226 & 261.4808 \\
6 & Ruban, D. A. & 244 & 214 & 213.4476 \\
7 & Coratza, P. & 232 & 228 & 220.1323 \\
8 & Gray, M. & 230 & 230 & 220.3576 \\
9 & Marković, S. B. & 208 & 207 & 188.0469 \\
10 & Panizza, M. & 202 & 222 & 189.7282 \\
11 & Henriques, M. H. & 143 & 218 & 134.3866 \\
12 & Nemeth, K. & 141 & 183 & 119.0049 \\
13 & Prosser, C. D. & 139 & 217 & 133.6692 \\
14 & Wimbledon, W. A. P. & 133 & 228 & 126.8341 \\
15 & Pereira, D. & 128 & 221 & 122.3453 \\
\hline
\end{tabular}

Figure 8 presents a map with a bibliographic network of 240 nodes/authors connected by cocitation links grouped into 11 clusters. The proximity between each node reveals the relationship of each author and the number of authors' citations in the document references represented by circles that vary in size.

In Table S3, the five most essential academics per cluster, as well as the 11 main research areas, are presented, considering their total link strength and meeting at least 20 cocitations, except for Cluster 11 , which only has two nodes/authors who satisfy this condition.

The five principal cocited authors in the papers in the first cluster (red colour; Figure 8, Table S3) of 56 nodes are: Reynard (441 cocitations), Coratza (232), Panizza (202), Pereira (128), and Pereira (99), whose main area of research is geomorphological heritage, in which methods to evaluate geomorphosites were proposed. As an improvement, to evaluate the scientific and additional values of geomorphosites from Reynard et al. [115], four main aspects were highlighted such as (i) the evaluation process, which was part of a broader phase divided into inventory and management, and a second stage (selection, assessment, use, evaluation); (ii) it was essential to carry out a selection process of potential geosites before their assessment; (iii) information was added to the assessment method on the use of geomorphosites; and (iv) mapping and representation during the evaluation phase were performed and at the end of the inventory (types of qualitative, univariate, bivariate, multivariate representation). There is a quantitative method to evaluate the scientific parts in a geomorphosite using Geographic Information System (GIS) tools [116]. Researchers such as Pereira and Pereira designed and applied a geomorphosite assessment method [117] in Montesinho Natural Park. This assessment method shows the stages of geomorphosite selection and its quantitative evaluation, which is applied to other protected areas independently of their size. 


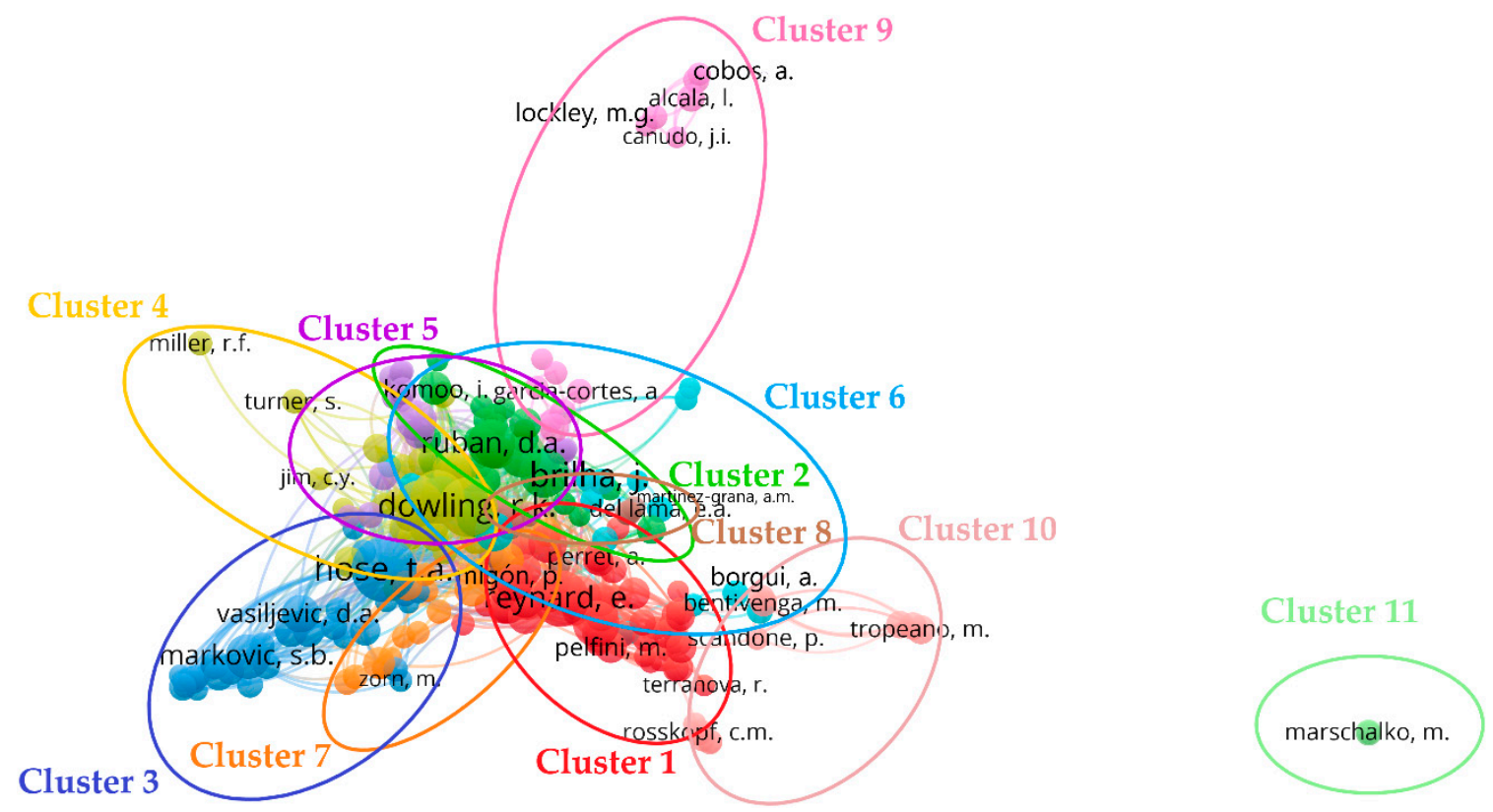

Figure 8. Author cocitation map during from 1984 to 2019.

Other scholars such as Panizza propose a definition for geomorphosites in a broader sense, whose characteristics qualify it as a component of the cultural heritage of a territory [118], proposing a discipline called "cultural geomorphology" [119]. This concerns geomorphological components of an area and incorporates more elements than the scientific, scenic, socioeconomic, and cultural values of the landscape, being one of the most pioneering pieces of research in conducting types of studies related to geocultural heritage $[119,120]$.

The second cluster (green colour) consists of 36 nodes, with the top five most cocited authors being: Brilha (278), Ruban (244), Henriques (143), Prosser (139), and Gordon (105), with a focus on geoheritage and geoconservation. Brilha [121] proposes a distinction between geosites (in-situ geodiversity sites with scientific value) and geodiversity sites (other values, such as educational, aesthetic, cultural, among others, depending on the potential use of the sites), and provides a better understanding of the terms geoheritage and geological heritage, which are occurrences of in-situ (geosite) and ex-situ geodiversity with an exceptional scientific value that can be of international or national relevance. Brilha [121] develops a quantitative method for the evaluation and inventory of geosites and geodiversity sites applied at different scales and considering different criteria, including the risk of degradation and concepts necessary for geoconservation strategies. Ruban, in his article "Quantification of Geodiversity and its Loss" [122], proposes a quantitative method for geodiversity assessment. This quantitative method is not based on a geodiversity index; rather, it is based on a sum of types of geosites present in the study area of which the method is associated with greater rigour to the geoheritage.

Other authors such as Henriques [101] provide evidence for the recognition of geoconservation as a new field of knowledge, where three purposes related to geoheritage are distinguished: (i) inventory and evaluation (Basic Geoconservation), (ii) conservation (defined as Applied Geoconservation), and (iii) valuation (Technical Applications of Geoconservation). Prosser describes the history, concepts, and practices of geoconservation [123-126], whereas Gordon [127] addresses a more comprehensive approach to geotourism with links between geoheritage, cultural heritage, and landscape, improving the tourist experience and promoting geo-education and geoconservation.

The third cluster (blue colour; Figure 8) consists of 33 nodes and shows the five most cocited authors: Hose (704), Marković (208), Vasiljevićć (119), Lukić (77), and Vujičić (56). The researchers of this group made contributions to topics related to geotourism, geosite assessment model (GAM) applications, and loess deposit. In this cluster, the author most recognised by this type of bibliometric 
analysis is Hose, an author who has contributed to the bases of the definition of geotourism with a geological approach [15]. This definition was redefined in $[22,25,103]$ which provided the historical and theoretical foundations of geotourism and its path towards sustainable management. Additionally, it describes geoconservation, geohistory, and geointerpretation, called the three key "3G", as aspects of modern geotourism [102]. Additionally, application of the preliminary geosite assessment model (GAM) as a quantitative method for the physical evaluation of geosites, based on indicators/subindicators are grouped in main and additional values, which helps in planning, the sustainable management of sites, their transformation into touristic destinations [98], and finally, how the loess deposits have become an essential element of Earth's geoheritage for applications in geotourism [105,128].

The fourth cluster (yellow colour) consists of 26 nodes, with the five most cocited authors being: Dowling (529 cocitations), Newsome (353), Gray (230), Zouros (127), and Costa (121), whose investigative content covers the lines of investigation of geotourism development, geodiversity, and their promotion through geoparks. Authors like Dowling and Newsome place geotourism as a tool for sustainable development and the development of rural communities and geoconservations [21,104,129]. Specifically, Newsome et al. [104] emphasise that inadequate management of geotourism can lead to an opposite effect of the sustainable development of geoheritages. The concept of geodiversity was initially provided by Gray and a greater understanding (theoretical, practical, and evolution) of the aspects related to geodiversity are developed by this author in [1]. Others like McKeever, and Zouros [130] provide a detailed description of the functions and benefits of geoparks for the community and the development of geology. Costa, in conjunction with other researchers, discusses the role that geoparks play in the conservation and management of knowledge [100] and the evaluation of innovative geoparks strategies for sociocultural sustainability by questionnaires sent to 64 geoparks declared by UNESCO [11].

The fifth cluster (purple colour) consist of 16 nodes, with the five most cocited authors being: Nemeth (141), Moufti (57), Erfurt-Cooper (46), Kereszturi (42), and Nkouathio (37), who study volcanic geoheritage. Scientists from this group have shown interest in this issue and its relationship with tourism aspects and volcanic research [131-135], where volcanic landforms are points of interest for geotourism and geo-education, and are considered witnesses to the power of nature [134].

The sixth cluster (light blue) consists of 16 nodes, with the five most cocited authors being Wimbledon (133), Robinson (37), del Lama, (36), Mansur (36), and Borghi (35), who cover topics related to Geological Heritage and Urban Geoheritage (Conservation and Management). Wimbledon [136] manifests the importance of geosite conservation in a report on the bases of the International Union of Geological Science (IUGS) project "Geosites". This report involves the geological community in geoconservation and exposes the protection initiatives applied in the national inventories of most European countries [137]. Robinson [138] presents the first geological theme park in the world called Crystal Palace Park with reconstructions of life-size fossil animals for geoeducation, which was one of the most significant events of geointerpretation and geoconservation leading to the development of geotourism in the United Kingdom. In Robinson's work [139], conservationists made up of the Geological Curators' Group and the Geoconservation Commission of the Geological Society met at the first geotourism conference in Belfast in 1998, an event where geologically based geotourism gained international recognition.

Researchers from this group also present new ways of preserving geological heritage in urban areas through urban geotourism, such as the set of sites (monuments, rocks, buildings, and squares, typical of the 19th century) where the georoute retains the old centre of Sao Paulo (Brazil) presented by del Lama [46], the Historic Ornamental Stones in the urban geological heritage of Turin (Italy) [112], and examples of urban geotourism in the project "Caminhos Geológicos" in Rio de Janeiro (Brazil) by Manzur [140].

The seventh cluster (orange colour) consists of 16 nodes, with the five most cocited authors being Migon (94), Kubalikova (72), Zgłobicki (62), Alexandrowicz (53), and Kirchner (50). They focus mainly on the study and evaluation of geosites and geomorphosites for the adequate development of 
geotourism, which significantly promotes the protection and geoconservation of the natural heritage that they possess [141-144].

The eighth cluster (brown colour) consists of 14 nodes, with the five most cocited authors being Rybar (58), Štrba (50), Fassoulas (31), Martinez-Grana (31), and Goy. (28). The members of this group researched natural object assessments for geotourism development and technologies applied to geoheritage management, emphasising the need for further research in the field of geosite evaluation for their planning and management at different regional, natural, and international scales [145], as well as the use of the geotourist trail as an essential tool for the educational development of natural heritage and geotourism [146]. Quantitative methods of geodiversity assessment using three-dimensional modelling solutions to visualise geodiversity indices in natural areas have been proposed [147]. The method of quantitative evaluation of geotopes includes not only geological and geographical value but also ecological, cultural, aesthetic, economic, and exploitation value within the area of a geopark (Fassoulas et al. [97]). In addition, the use of augmented reality and virtual reality technologies to promote geodiversity through virtual geological itineraries in the works by Martínez-Graña, Goy, and Cimarra [148].

The ninth cluster (pink colour) consists of 13 nodes, with the five most cocited authors being Ávila (48), Alcalá (44), Carcavilla (34), Cobos (33), and Lockley (31). They carried out studies related to palaeontological heritage resources such as the scientific and tourist evaluation of palaeontological sites on Santa Maria Island and exposed relevant geosites such as Pedra-que-Pica [5] and an integrated dinosaur site heritage management system using GIS [149]. Additionally, methods for the evaluation of geodiversity to identify the places of geological interest that includes those of palaeontological type, based on a set of criteria to reduce subjectivity [150].

The tenth cluster (coral colour) consists of 12 nodes, with the most cocited authors being Tropeano (48), Sabato (44), Pieri (41), Bentivenga (39), and Rosskopf (39). These authors show some places that are examples of the study and geotourism of palaeogeography, speleological, and anthropic landscapes that promote geocultural education [151-158].

The eleventh cluster (light green colour) consists of two nodes, with the most cocited authors being Marschalko (32) and Yilmaz (23), whose research area is Engineering Geology in Geotourism. This cluster provides a new form of geotourism, taking advantage of geological engineering tools. For example, in the eight historical churches of the Czech Republic, it is possible to appreciate the phenomenon of differential subsidence resulting from underground mining, which are monuments preserved by man. An example of the effects of subsidence from underground coal mining $[159,160]$ and studies have additionally been presented in relation to the long-term effects of mining on the landscape [161].

\subsubsection{Coauthorship Analysis}

This analysis provides the relationship between authors who collaborate with the research field. Of the 1252 authors present in this database, only 22 have generated five documents by themselves or in coauthorship. Figure 9a shows two correlated groups of the 22 authors, with six being related to each other.

Cluster 1 (red colour) shows a total of four authors ("Hose", "Vasiljević", "Lukić", and "Vujičić"), having Hose as the most influential author in the research field. With the highest number of occurrences (530), it also has five connections within this analysis, thus achieving a relationship with the other authors with whom they collaborated. Cluster 2 (green colour) contains two authors ("Marković" and "Tomić"). Marković (224 occurrences) collaborated with some authors in Cluster 1. Tomić has the least collaborations with other authors (only four connections) and is located further to the end of Figure 9a.

The same cluster system is shown in Figure $9 \mathrm{~b}$ albeit with a representation of the evolution in years of the appearance of each one, thus having Hose (with 13 articles) as the author with the 
most experience in the area, Marković (12 articles) as the author with excellent experience and high collaborative field, and Tomić (seven articles) as the youngest author. As a result, he is further away.

(a)

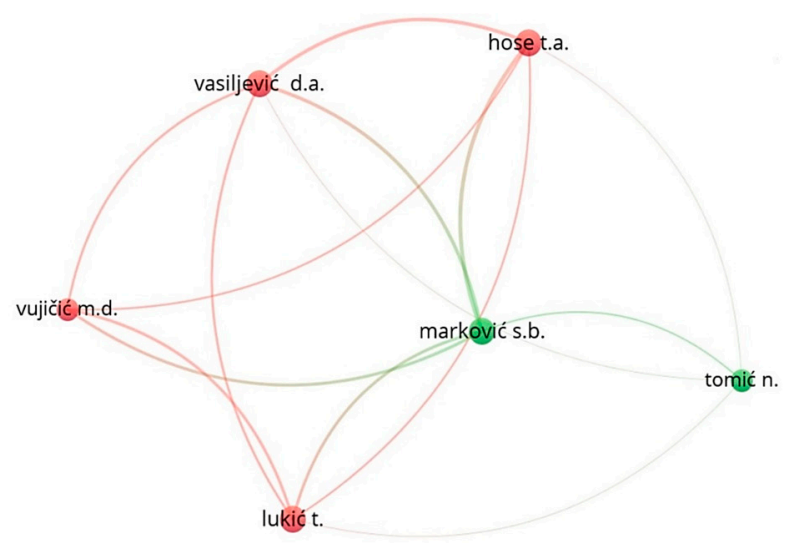

(b)

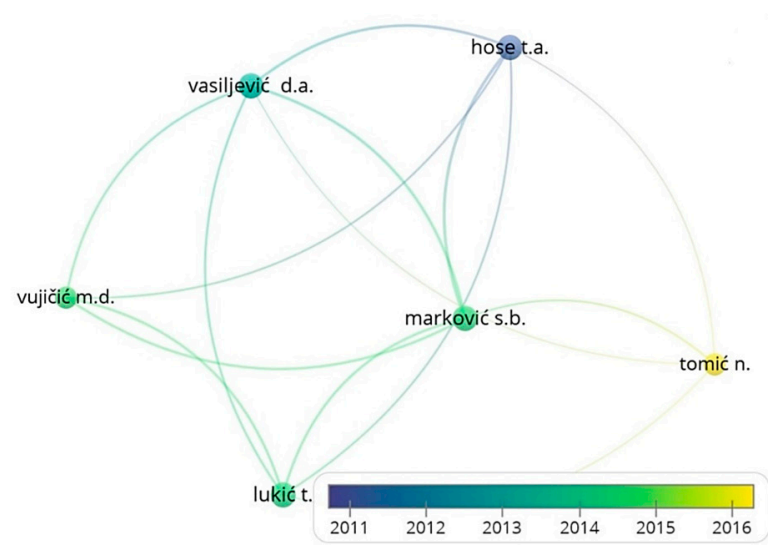

Figure 9. Author coauthorship map from 1984 to 2019. (a) A cluster distribution map; (b) evolutionary map in the appearance of authors.

\section{Results, Analysis and Discussion}

Based on the results of the different bibliometric analyses applied in the present study, the number of citations should not be considered as the only unit to determine the influence or importance of an element of analysis. For example, Hose is the most cited and cocited author for geotourism with 530 citations (Figure 5b) and 704 cocitations (Table 3), respectively. When observing the author cocitation map (Figure 8), the most active area of research (in red colour) is identified to be Cluster 1 , which focuses mainly on geomorphological heritage and has the most significant number of referenced academics (56 nodes). Reynard is the most cited author of this cluster and Hose is not part of this group.

Authors of Cluster 1 (Figure 8) have proposed various methods for the evaluation of geomorphosites, such as an improved version to evaluate the scientific and additional values of geomorphosites and Reynard's [115] quantitative method for the evaluation of the scientific part in a geomorphosite, using a Geographic Information Systems (GIS) tool [116]. Researchers such as Pereira and Pereira designed and applied a geomorphosite assessment method that was also applied to other protected areas [117].

Hose, despite leading "the 15 top authors most cocited in 1984-2019" (Table S3), is located in Cluster 3 alongside other researchers (33 nodes) who addressed issues related to geotourism, GAM application, and how the loess deposits (eolian sediment that is an essential archive of quaternary climate changes) have become essential elements of geoheritage for their application as geotourism [105]. These elements necessary are for scientific, tourist, and educational value, and, additionally, for cultural and social aspects [128]. Hose has contributed to the foundations of the definition of geotourism with a geological approach [15]. Hose's concept was redefined [22,25,103] and has provided the historical and theoretical 
foundations of geotourism and its path towards sustainable management. Geoconservation, geohistory, and geointerpretation are described as the three key "3G" aspects of modern geotourism [102].

A similar vision is identified when comparing productivity according to the number of publications of the author and the most cited article. Focusing on the number of articles published, we have the author Ruban with 23 documents followed by Hose with 13 (Figure 5a). Dowling's work entitled "Geotourism's Global Growth" [48] is the most widely cited work on the subject with 158 citations. Dowling describes geotourism's nature and characteristics, the trends and growth of this discipline, and concludes with some critical elements in the development of geotourism.

Scientific productivity analysis focuses on the annual production of published articles, with three periods in scientific growth defined from 1984 to 2019 (Figure 4). These include introduction, the theoretical development of geotourism, and diversification of information based on the historical curvature of the number of citations received per year in relation to the published article. Therefore, by making a linear and exponential graphical adjustment to the annual growth curve (Figure 3), according to Price's Law, a growth pattern of the research topic is observed, and the research field of geotourism is shown to be in a phase of exponential growth with an $\mathrm{R}^{2}$ value of 0.9270 and an exponential trajectory higher than the linear one.

Of the 506 documents analysed, there are a total of 1252 authors who have provided significant geoscientific contributions during the research period in the different 66 countries identified. According to contributions by countries and regions, European countries such as Poland and the United Kingdom are recognised as the most productive according to the number of documents (52 in Poland; Figure 5a) and citations (954 of the United Kingdom; Figure 5b).

Studies related to the geotourism that use bibliometric analyses have been presented, such as the geographical review of the literature on geotourism [52]; research by Ólafsdóttir and Tverijonaite [54], and Ólafsdóttir [55]; bibliometric analysis by Ibáñez, Brevik, and Cerdà [58]; and a systematic literature review (SLR) of geotourism and territorial development [59]. Although the time interval for the systematic literature search is limited, they have contributed with knowledge of the intellectual structure of the study research field and its associated topics (Geodiversity, Geopark, Geoheritage).

The majority of studies conclude that there is a geographical pattern of geotourism research concentrated in Europe (mainly Italy, Poland, United Kingdom), Brazil, Australia, and China. In particular, highlighting the most pressing needs in future studies, evaluating the positive and negative impacts, and providing knowledge of geotourism stakeholders and their relationship with sustainable development and geoconservation.

However, the present work covers the geotourism research field evolved over the last 25 years, albeit with some limitations, such as the use of a single database (Scopus), a single type of documents (articles), and a single language (English). The selection of words, time coverage, and the number of documents used allow presenting a research work that can serve as a reference for future researchers in the field of geotourism. The top 15 countries and regions that contributed the most in the world during the search period from 1984 to 2019 agree with previously cited bibliometric studies [52,54,55,58,59]. There is a geographical pattern of geotourism research concentrated in the European continent; however, Italy (one of the largest geotourism research communities) is not part of the top 15 most contributions of articles by country. Instead, it is located within the top three according to the analysis of the number of citations (Figure 5b).

Regarding the impact and productivity of scientific journals, of the 142 analysis journals, Geoheritage has the most significant number of published articles (165), the largest number of citations (1818), and a Q2 rank according to the evaluation by quartiles in SJR (Table S1). Based on the impact factor (H-index), the journal "Quaternary International" has a value of 93 given its six published articles, is in the Q1 range, and has 120 citations, placing it in Position 6 based on the number of citations. Considering the small number of articles produced by the journal is a criterion that highlights its importance. The study area "Earth and Planetary Sciences" is present in more than $50 \%$ of journals, demonstrating its high geoscientific interest and contribution to journals that focus 
on the heritage elements of sites. In addition to geoeducation, geointerpretation and geotourism are means for the sustainable development of the sector.

Bibliometric analysis of the co-occurrences of author keywords shows the evolutionary field of the research topic, which is why the database is divided into the three periods previously identified, thus making it possible to perform an interpretation of conceptual evolution by phases. In the introduction phase (Period I), the term geotourism begins. Its connections with various areas and terms (Figure 7), relating approaches, or reasons to visit attractive and geological places-in addition to the study and geoconservation of geological resources-is present in unique areas and recognised through geotourism. In the development phase (Period II), geotourism focuses on and relates to places with high geological importance such as geosites, geoheritage, and geoparks, promoting geoconservation and sustainable development of the sites and the geodiversity they possess (Figure 8). Finally, in the growth phase (Period III), significant growth takes place in topics that were previously part of geotourism and now have their area, such as geoheritage and geoconservation (which includes geodiversity), geopark (which includes sustainable development), and geosite (volcanic geoheritage being a recently explored branch).

\section{Conclusions}

The present study offers an analysis of the intellectual structure of geotourism from a multidisciplinary point of view. It presents a more recent vision in the development of the research field that expands and enriches other previous studies by exhibiting a larger and more current data set ( $n=504 ; 1984-2019)$, focused on documents with a rigorous pairwise review process (articles) that are considered to possess certified knowledge.

This study provides a methodological contribution in the field of geotourism by presenting a bibliometric analysis that allows the evaluation of scientific production, as well as its visualisation with three bibliometric mapping techniques (co-occurrence analysis of keywords, author cocitations analysis, and coauthorship analysis), facilitating the knowledge of its structure and the development of the field of study.

The article revealed that geotourism has experienced sustained growth around the world, which can be examined by its production and citations over the years (Figure 4), allowing us to define three phases of the geoscientific evolution of geotourism and the current exponential growth it has manifested. Moreover, Price's Law (Figure 3) has shown that geotourism, from the beginning, is associated with a focus of study, motivation, and conservation of natural and geological resources, generating branches or areas such as geosites, geoheritage, and geoparks driven by geotourism. Additionally, over the years, this field of research has increased while maintaining a close relationship to its roots.

Growing interest in the field is evident considering 506 articles written by 1252 authors and their research exhibited in 142 journals, from universities and research centres in 66 countries. In these contributions, Hose (who started geotourism) is the most recognized in both citations and cocitations (Figure 5b and Table 3), followed by Dowling with his article "Geotourism's Global Growth" (Table 2). Downling's whose work is the most cited on the subject. Both authors have made significant research contributions through the journal Geoheritage, one of the most representative in terms of content and quantity of articles presented concerning geotourism (Table S1).

The use of bibliometric maps provides an interesting and revealing visual history of the research field. It can observe the emergence, development, and decline of topics related to geotourism (Figure 7), in addition to the contributions of the various authors of citations in the references that are grouped by subject (Figure 8 ) or contributions of current authors (Figure 9). These maps allow us to define some conclusions:

- Co-occurrence analysis of keywords: This analysis revealed existing topics and substantial changes in the intellectual structure of geotourism, as well as the stability and strength of other topics (Figure 7). The central themes are related to geotourism, geoheritages, geosites, geoconservations, 
geoparks, and geodiversity. The study further shows that the topics of geodiversity, geoparks, and geoheritage have persisted for 35 years (1984-2019) in the field of geotourism (Figure 7a-c). These topics are interrelated and part of the intellectual structure of geotourism. These results support what is stated by other bibliometric studies and other topics that are considered relevant in this field that appear in Figure 7c, such as sustainability and sustainable development, where geotourism - specifically in rural areas-is considered a tool to reach these topics about what is discussed in Section 4, "Results, Analysis and Discussion".

- Author cocitations analysis: The present study has identified 11 research areas within geotourism ranging from "geomorphological heritage" to the emerging line of research from "engineering geology in geotourism" (Figure 8, Table S3), where geomorphological heritage is the most active area of research. This research area has the most significant number of referenced researchers (56) whose works have proposed numerous quantitative methods and models to evaluate geomorphosites, definitions of a general nature of geomorphosites, and concepts that encompass a broader meaning as a component of the cultural heritage of the territory. The results obtained also showed that more research is required in the "engineering geology in geotourism" area. In this area, significant scientific, tourist, and economic potential is projected for the future in questions related to the sources of geological hazards and ways to reduce their impact, and how this raises awareness in the community.

- Coauthorship analysis: The study has identified 1252 authors representing the intellectual structure of which 22 present at least five documents, allowing us to understand the lines of thought related to these authors and their patterns of collaboration (Figure 9).

Finally, this study has some limitations: First, the use of a single database (Scopus) and not considering other databases that frequently used in the academic world such as Web of Science or Dimensions. Second, the consideration of a single type of document (articles) instead of expanding knowledge by using books, book chapters, conference articles, among others. Third, considering only articles in English, which, despite being the majority, potentially exclude significant contributions in other languages. However, the study presents a rigorous methodology for the selected documents and the use of a database considered reliable among researchers around the world. The selection of words, time coverage, and the number of documents used allow presenting a research work that can serve as a reference for future researchers in the field of geotourism. Future research could profitably extend our analytical approach to another language (e.g., Chinese, German, French, and Spanish), develop a comprehensive global vision of the literature, and include another type of document.

Supplementary Materials: The following are available online at http://www.mdpi.com/2076-3263/10/10/379/s1, Table S1. Top 15 most published journals; Table S2. The number of co-occurrences of the selected keywords per cluster; Table S3. Top author cocitation per cluster with stronger links based on author's reference.

Author Contributions: Conceptualisation, P.C.-M., G.H.-F., and N.M.-B.; methodology, P.C.-M., G.H.-F., N.M.-B., B.A.-M., and M.J.-M.; writing-original draft preparation, G.H.-F., P.C.-M., N.M.-B., B.A.-M., and M.J.-M.; writing-review and editing, P.C.-M., G.H.-F., N.M.-B., B.A.-M., and M.J.-M.; supervision, G.H.-F. All authors have read and agreed to the published version of the manuscript.

Funding: This research received no external funding.

Acknowledgments: This research study was possible with the valuable contribution of the "Registry of geological and mining heritage and its impact on the defence and preservation of geodiversity in Ecuador" academic research project by ESPOL University under grant nos. CIPAT-01-2018; UPSE University research project "Peninsula Santa Elena Geopark Project”; "Geoparque Ruta del Oro” (Gold Route) academic research project; the support of NOVA Science Research Associates and Geo-resources and Applications GIGA, ESPOL.

Conflicts of Interest: The authors declare no conflict of interest. 


\section{References}

1. Gray, M. Geodiversity: Developing the paradigm. Proc. Geol. Assoc. 2008, 119, 287-298. [CrossRef]

2. Mero, P.C.; Franco, G.H.; Briones, J.; Caldevilla, P.; Domínguez-Cuesta, M.J.; Berrezueta, E. Geotourism and local development based on geological and mining sites utilization, zaruma-portovelo, Ecuador. Geosciences 2018, 8, 205. [CrossRef]

3. Gray, M. Geodiversity: The Backbone of Geoheritage and Geoconservation; Elsevier Inc.: Amsterdam, The Netherlands, 2018; ISBN 9780128095423.

4. Reynard, E.; Brilha, J. Geoheritage: A multidisciplinary and applied research topic. In Geoheritage; Elsevier: Amsterdam, The Netherlands, 2018; pp. 3-9, ISBN 9780128095423.

5. Ávila, S.P.; Cachão, M.; Ramalho, R.S.; Botelho, A.Z. The Palaeontological Heritage of Santa Maria Island (Azores: NE Atlantic): A Re-evaluation of Geosites in GeoPark Azores and Their Use in Geotourism. Geoheritage 2015, 8, 155-171. [CrossRef]

6. Alexandrowicz, Z.; Urban, J.; Miśkiewicz, K. Geological Values of Selected Polish Properties of the UNESCO World Heritage List. Geoheritage 2009, 1, 43-52. [CrossRef]

7. Cai, Y.; Wu, F.; Han, J.; Chu, H. Geoheritage and Sustainable Development in Yimengshan Geopark. Geoheritage 2019, 11, 991-1003. [CrossRef]

8. Bonomo, A.E.; Acito, A.M.; Prosser, G.; Rizzo, G.; Munnecke, A.; Koch, R.; Bentivenga, M. Matera's Old Quarries: Geological and Historical Archives That Need Protection and Valorization. Geoheritage 2019, 11, 1603-1619. [CrossRef]

9. Ruban, D.A. Geodiversity as a precious national resource: A note on the role of geoparks. Resour. Policy 2017, 53, 103-108. [CrossRef]

10. Farsani, N.T.; Coelho, C.; Costa, C. Geotourism and geoparks as novel strategies for socio-economic development in rural areas. Int. J. Tour. Res. 2011, 13, 68-81. [CrossRef]

11. Farsani, N.T.; Coelho, C.; Costa, C. Geotourism and Geoparks as Gateways to Socio-cultural Sustainability in Qeshm Rural Areas, Iran. Asia Pac. J. Tour. Res. 2012, 17, 30-48. [CrossRef]

12. Brilha, J. Geoheritage: Inventories and evaluation. Geoheritage Assess. Prot. Manag. 2018, 69-85. [CrossRef]

13. Newsome, D.; Dowling, R. Geoheritage and Geotourism; Elsevier Inc.: Amsterdam, The Netherlands, 2018; ISBN 9780128095423.

14. Prosser, C.D.; Díaz-Martínez, E.; Larwood, J.G. The conservation of geosites: Principles and practice. Geoheritage Assess. Prot. Manag. 2018, 193-212. [CrossRef]

15. Hose, T. Selling the story of Britain's stone. Environ. Interpret. 1995, 10, 16-17.

16. Štrba, L.; Kršák, B.; Molokáč, M.; Adamkovič, J. Geotourism and geoparks-A sustainable form of environmental protection. In Production Management and Engineering Sciences, Proceedings of the International Conference on Engineering Science and Production Management (ESPM 2015), Tatranské Matliare, High Tatras Mountains, Slovak, 16-17 April 2015; CRC Press: Boca Raton, FL, USA, 2015; pp. 279-284. [CrossRef]

17. Lew, A.A. Editorial: Geotourism and what geographers do. Tour. Geogr. 2002, 4, 347-348. [CrossRef]

18. Arouca Declaration on Geotourism November 12, 2011 Portugal. Available online: http://www.europeangeoparks. org/?p=223 (accessed on 18 September 2020).

19. Larwood, J.; Prosser, C. Geotourism, Conservation and Society Earth heritage conservation in the UK-Its status Conservation and geotourism-Some examples from the UK. Geol. Balc. 1998, 28, 97-100.

20. Frey, M.L. Geologie-Geo-Tourismus-Umweltbildung: Themen und Tätigkeitsbereiche im Spannungsfeld Ökonomie und Nachhaltige Entwicklung-Terra Nostra. Schr. Alfred-Wegener Stift. 1998, 98, V85.

21. Newsome, D.; Dowling, R.K. Setting an agenda for geotourism. Geotour. Tour. Geol. Landsc. $2010,1-12$. [CrossRef]

22. Hose, T.A.; Vasiljević, D.A. Defining the Nature and Purpose of Modern Geotourism with Particular Reference to the United Kingdom and South-East Europe. Geoheritage 2012, 4, 25-43. [CrossRef]

23. Dowling, R.K. Global Geotourism-An Emerging Form of Sustainable Tourism. Czech J. Tour. 2014, 2, 59-79. [CrossRef]

24. Hose, T.A. Geoheritage and Geotourism: A European Perspective; Boydell \& Brewer, Woodbridge: Woodbridge, UK, 2016.

25. Hose, T.A. European Geotourism-Geological Interpretation and Geoconservation Promotion for Tourists; Barretino: Madrid, Spain, 2000; ISBN 8478404171. 
26. Słomka, T.; Kicińska-Świderska, A. The basic concepts of geotourism. Geoturystyka/Geotourism 2004, 1, 5-7.

27. De Ruchkys, U.A. Patrimônio Geológico e Geoconservação do Quadrilátero Ferrífero. Ph.D. Thesis, Universidade Federal de Minas Gerais, Minas Gerais, Brazil, 2005.

28. Joyce, E.B. Geological heritage of Australia: Selecting the best for Geosites and World Heritage, and telling the story for geotourism and Geoparks. ASEG Ext. Abstr. 2006, 2006, 1-4. [CrossRef]

29. Sadry, B.N. Fundamentals of geotourism: With emphasis on Iran. Retrieved March 2009, 14, 2015.

30. Amrikazemi, A. Atlas of Geopark E Geotourism Resources of Iran: Geoheritage of Iran; Geological Survey of Iran, Tehran: Tehran, Iran, 2010; ISBN 978-964-6178-39-7.

31. Newsome, D.; Dowling, R.K. The future of geotourism where to from here. In Geotourism: The Tourism of Geology and Landscape; Goodfellow Publishers: Oxford, UK, 2010.

32. Hose, T.A. The english origins of geotourism (as a vehicle for geoconservation) and their relevance to current studies. Acta Geogr. Slov. 2011, 51, 343-360. [CrossRef]

33. Herrera-Franco, G.; Carrión-Mero, P.; Alvarado, N.; Morante-Carballo, F.; Maldonado, A.; Caldevilla, P.; Briones-Bitar, J.; Berrezueta, E. Geosites and Georesources to Foster Geotourism in Communities: Case Study of the Santa Elena Peninsula Geopark Project in Ecuador. Sustainability 2020, 12, 4484. [CrossRef]

34. Herrera, G.; Carrión, P.; Briones, J. Geotourism potential in the context of the Geopark project for the development of Santa Elena province, Ecuador. WIT Trans. Ecol. Environ. 2018, 217, 557-568. [CrossRef]

35. Castanera, D.; Pascual, C.; Canudo, J.I.; Barco, J.L. Bringing Together Research, Geoconservation and Reaching a Broad Public in the Form of a Geotourism Project: The Ichnite Route of Soria (Spain). Geoheritage 2018, 10, 393-403. [CrossRef]

36. Mata-Perelló, J.; Carrión, P.; Molina, J.; Villas-Boas, R. Geomining heritage as a tool to promote the social development of rural communities. Geoheritage Assessment, Prot. Manag. 2018, 167-177. [CrossRef]

37. Carrión-Mero, P.; Loor-Oporto, O.; Andrade-Ríos, H.; Herrera-Franco, G.; Morante-Carballo, F.; Jaya-Montalvo, M.; Aguilar-Aguilar, M.; Torres-Peña, K.; Berrezueta, E. Quantitative and Qualitative Assessment of the "El Sexmo" Tourist Gold Mine (Zaruma, Ecuador) as A Geosite and Mining Site. Resources 2020, 9, 28. [CrossRef]

38. Farsani, N.T.; Mortazavi, M.; Bahrami, A.; Kalantary, R.; Bizhaem, F.K. Traditional Crafts: A Tool for Geo-education in Geotourism. Geoheritage 2017, 9, 577-584. [CrossRef]

39. Franco, G.H.; Mero, P.C.; Carballo, F.M.; Narváez, G.H.; Bitar, J.B.; Torrens, R.B. Strategies for the development of the value of the mining-industrial heritage of the Zaruma-Portovelo, ecuador, in the context of a geopark project. Int. J. Energy Prod. Manag. 2020, 5, 48-59. [CrossRef]

40. Kim, S.S.; Kim, M.; Park, J.; Guo, Y. Cave tourism: Tourists' characteristics, motivations to visit, and the segmentation of their behavior. Asia Pacific J. Tour. Res. 2008, 13, 299-318. [CrossRef]

41. Garofano, M.; Govoni, D. Underground Geotourism: A Historic and Economic Overview of Show Caves and Show Mines in Italy. Geoheritage 2012, 4, 79-92. [CrossRef]

42. Erfurt-Cooper, P. Geotourism in volcanic and geothermal environments: Playing with fire? Geoheritage 2011, 3, 187-193. [CrossRef]

43. Reynard Emmanuel Scientific research and tourist promotion of geomorphological heritage. Geogr. Fis. Din. Quat. 2008, 31, 225-230.

44. Allan, M.; Dowling, R.K.; Sanders, D. The motivations for visiting geosites: The case of crystal cave, Western Australia. Geoj. Tour. Geosites 2015, 16, 142-153.

45. Ng, Y.; Fung, L.W.; Newsome, D. Hong Kong Geopark: Uncovering the geology of a metropolis. In Global Geotourism Perspectives; Goodfellow Publishers Limited: Wallingford, Oxfordshire, UK, 2010.

46. Del Lama, E.A.; de La Corte Bacci, D.; Martins, L.; da Glória Motta Garcia, M.; Dehira, L.K. Urban Geotourism and the Old Centre of São Paulo City, Brazil. Geoheritage 2015, 7, 147-164. [CrossRef]

47. Palacio-Prieto, J.L. Geoheritage Within Cities: Urban Geosites in Mexico City. Geoheritage 2014, 7, $365-373$. [CrossRef]

48. Dowling, R.K. Geotourism's Global Growth. Geoheritage 2011, 3, 1-13. [CrossRef]

49. Brown, G. Mapping Landscape Values and development preferences: A method for tourism and residential development planning. Int. J. Tour. Res. 2006, 8, 101-113. [CrossRef]

50. UNESCO List of UNESCO Global Geoparks (UGGp). Available online: http://www.unesco.org/new/en/ natural-sciences/environment/earth-sciences/unesco-global-geoparks/list-of-unesco-global-geoparks/ (accessed on 18 September 2020). 
51. Pralong, J.P. Geotourism: A new Form of Tourism utilising natural Landscapes and based on Imagination and Emotion. Tour. Rev. 2006, 61, 20-25. [CrossRef]

52. Ruban, D.A. Geotourism-A geographical review of the literature. Tour. Manag. Perspect. 2015, 15, 1-15. [CrossRef]

53. Dowling, R.; Newsome, D. Handbook of Geotourism; Dowling, R., Newsome, D., Eds.; Edward Elgar Publishing: Cheltenham, UK, 2018; ISBN 9781785368851.

54. Ólafsdóttir, R.; Tverijonaite, E. Geotourism: A systematic literature review. Geosciences 2018, 8, 234. [CrossRef]

55. Ólafsdóttir, R. Geotourism. Geosciences 2019, 9, 48. [CrossRef]

56. De la Cruz del Río-Rama, M.; Maldonado-Erazo, C.P.; Álvarez-García, J.; Durán-Sánchez, A. Cultural and natural resources in tourism Island: Bibliometric mapping. Sustainability 2020, 12, 724. [CrossRef]

57. Dowling, R.K.; Newsome, D. Global Geotourism Perspectives; Goodfellow Publishers Limited: Oxford, UK, 2010.

58. Ibáñez, J.-J.; Brevik, E.C.; Cerdà, A. Geodiversity and geoheritage: Detecting scientific and geographic biases and gaps through a bibliometric study. Sci. Total Environ. 2019, 659, 1032-1044. [CrossRef] [PubMed]

59. Duarte, A.; Braga, V.; Marques, C.; Sá, A.A. Geotourism and Territorial Development: A Systematic Literature Review and Research Agenda. Geoheritage 2020, 12, 65. [CrossRef]

60. Van Eck, N.J.; Waltman, L. Visualizing Bibliometric Networks. In Measuring Scholarly Impact; Springer International Publishing: Cham, Switzerland, 2014; pp. 285-320, ISBN 9783319103778.

61. Price, D.J.D.S. Networks of Scientific Papers. Science 1965, 149, 510-515. [CrossRef]

62. Mao, G.; Huang, N.; Chen, L.; Wang, H. Research on biomass energy and environment from the past to the future: A bibliometric analysis. Sci. Total Environ. 2018, 635, 1081-1090. [CrossRef]

63. Soosaraei, M.; Khasseh, A.A.; Fakhar, M.; Hezarjaribi, H.Z. A decade bibliometric analysis of global research on leishmaniasis in Web of Science database. Ann. Med. Surg. 2018, 26, 30-37. [CrossRef]

64. Tao, J.; Qiu, D.; Yang, F.; Duan, Z. A bibliometric analysis of human reliability research. J. Clean. Prod. 2020, 260, 121041. [CrossRef]

65. Carrión-Mero, P.; Montalván-Burbano, N.; Paz-Salas, N.; Morante-Carballo, F. Volcanic Geomorphology: A Review of Worldwide Research. Geosciences 2020, 10, 347. [CrossRef]

66. Chang, Y.W.; Huang, M.H.; Lin, C.W. Evolution of research subjects in library and information science based on keyword, bibliographical coupling, and co-citation analyses. Scientometrics 2015, 105, 2071-2087. [CrossRef]

67. Montalván-Burbano, N.; Pérez-Valls, M.; Plaza-Úbeda, J. Analysis of scientific production on organizational innovation. Cogent Bus. Manag. 2020, 7. [CrossRef]

68. Parish, A.J.; Boyack, K.W.; Ioannidis, J.P.A. Dynamics of co-authorship and productivity across different fields of scientific research. PLOS ONE 2018, 13, e0189742. [CrossRef] [PubMed]

69. Qiu, J.P.; Dong, K.; Yu, H.Q. Comparative study on structure and correlation among author co-occurrence networks in bibliometrics. Scientometrics 2014, 101, 1345-1360. [CrossRef]

70. Small, H.G. A Co-Citation Model of a Scientific Specialty: A Longitudinal Study of Collagen Research. Soc. Stud. Sci. 1977, 7, 139-166. [CrossRef]

71. Tranfield, D.; Denyer, D.; Smart, P. Towards a Methodology for Developing Evidence-Informed Management Knowledge by Means of Systematic Review* Introduction: The need for an evidence- informed approach. Br. J. Manag. 2003, 14, 207-222. [CrossRef]

72. Denyer, D.; Tranfield, D. Producing a systematic review. In The Sage Handbook of Organizational Research Methods; Sage Publications Ltd.: London, UK, 2009; pp. 671-689.

73. Fahimnia, B.; Sarkis, J.; Davarzani, H. Green Supply Chain Management: A Review and Bibliometric Analysis; Elsevier: Amsterdam, the Netherlands, 2015; Volume 162, ISBN 1508831483.

74. Keathley-Herring, H.; Van Aken, E.; Gonzalez-Aleu, F.; Deschamps, F.; Letens, G.; Orlandini, P.C. Assessing the maturity of a research area: Bibliometric review and proposed framework. Scientometrics 2016, 109, 927-951. [CrossRef]

75. Do Prado, J.W.; de Castro Alcântara, V.; de Melo Carvalho, F.; Vieira, K.C.; Machado, L.K.C.; Tonelli, D.F. Multivariate analysis of credit risk and bankruptcy research data: A bibliometric study involving different knowledge fields (1968-2014). Scientometrics 2016, 106, 1007-1029. [CrossRef]

76. Zupic, I.; Čater, T. Bibliometric Methods in Management and Organization. Organ. Res. Methods 2015, 18, 429-472. [CrossRef] 
77. Liu, X. Full-Text Citation Analysis: A New Method to Enhance. J. Am. Soc. Inf. Sci. Technol. 2013, 64, 1852-1863. [CrossRef]

78. Van Eck, N.J.; Waltman, L. Software survey: VOSviewer, a computer program for bibliometric mapping. Scientometrics 2010, 84, 523-538. [CrossRef] [PubMed]

79. Cobo, M.J.; López-Herrera, A.G.; Herrera-Viedma, E.; Herrera, F. Science mapping software tools: Review, analysis, and cooperative study among tools. J. Am. Soc. Inf. Sci. Technol. 2011, 62, 1382-1402. [CrossRef]

80. Cobo, M.J.; López-Herrera, A.G.; Herrera-Viedma, E.; Herrera, F. An approach for detecting, quantifying, and visualizing the evolution of a research field: A practical application to the Fuzzy Sets Theory field. J. Informetr. 2011, 5, 146-166. [CrossRef]

81. Hallinger, P.; Suriyankietkaew, S. Science Mapping of the Knowledge Base on Sustainable Leadership, 1990-2018. Sustainability 2018, 10, 4846. [CrossRef]

82. Harzing, A.W.; Alakangas, S. Google Scholar, Scopus and the Web of Science: A longitudinal and cross-disciplinary comparison. Scientometrics 2016, 106, 787-804. [CrossRef]

83. Scopus Content Coverage Guide; Elsevier: Amsterdam, the Netherlands, 2020.

84. Ruban, D.; Ponedelnik, A.; Yashalova, N. Megaclasts: Term Use and Relevant Biases. Geosciences 2018, 9, 14. [CrossRef]

85. Becker, C.; Maier, J.; Ruppert, K.; Weber, P.; Wolf, K. Geographical tourism research in the Federal Republic of Germany. GeoJournal 1984, 9, 37-40. [CrossRef]

86. Lozato-Giotart, J.P. Geographical rating in tourism development. Tour. Manag. 1992, 13, 141-144. [CrossRef]

87. Geremia, F.; Massoli-Novelli, R. Coastal geomorphosites of the Isles of Lipari and Stromboli (Aeolian islands, Italy): New potential for geo-tourism. Alp. Mediterr. Quat. 2005, 18, 233-244.

88. Cisneros, L.; Ibanescu, M.; Keen, C.; Lobato-Calleros, O.; Niebla-Zatarain, J. Bibliometric Study of Family Business Succession Between 1939 and 2017: Mapping and Analyzing Authors' Networks; Springer International Publishing: Budapest, Hungary, 2018; Volume 117, ISBN 0123456789.

89. Martín-Martín, A.; Orduna-Malea, E.; Thelwall, M.; Delgado López-Cózar, E. Google Scholar, Web of Science, and Scopus: A systematic comparison of citations in 252 subject categories. J. Informetr. 2018, 12, 1160-1177. [CrossRef]

90. North, M.A.; Hastie, W.W.; Hoyer, L. Out of Africa: The underrepresentation of African authors in high-impact geoscience literature. Earth-Sci. Rev. 2020, 208, 103262. [CrossRef]

91. Scarlett, J.P.; Riede, F. The Dark Geocultural Heritage of Volcanoes: Combining Cultural and Geoheritage Perspectives for Mutual Benefit. Geoheritage 2019, 11, 1705-1721. [CrossRef]

92. Hallinger, P.; Nguyen, V.-T. Mapping the Landscape and Structure of Research on Education for Sustainable Development: A Bibliometric Review. Sustainability 2020, 12, 1947. [CrossRef]

93. Van Eck, N.J.; Waltman, L. Citation-based clustering of publications using CitNetExplorer and VOSviewer. Scientometrics 2017, 111, 1053-1070. [CrossRef] [PubMed]

94. Povedano Montero, F.J.; López-Muñoz, F.; Hidalgo Santa Cruz, F. Análisis bibliométrico de la producción científica española en el área de la Optometría. Arch. Soc. Esp. Oftalmol. 2016, 91, 160-169. [CrossRef] [PubMed]

95. De Solla Price, D.J. Little Science, Big Science; Columbia University Press: New York, NY, USA, 1963.

96. Gordon, J.E. Rediscovering a Sense of Wonder: Geoheritage, Geotourism and Cultural Landscape Experiences. Geoheritage 2012, 4, 65-77. [CrossRef]

97. Fassoulas, C.; Mouriki, D.; Dimitriou-Nikolakis, P.; Iliopoulos, G. Quantitative Assessment of Geotopes as an Effective Tool for Geoheritage Management. Geoheritage 2012, 4, 177-193. [CrossRef]

98. Vujičić, M.D.; Vasiljević, D.A.; Marković, S.B.; Hose, T.A.; Lukić, T.; Hadžić, O.; Janićević, S. Preliminary geosite assessment model (GAM) and its application on fruška gora mountain, potential geotourism destination of Serbia. Acta Geogr. Slov. 2011, 51, 361-377. [CrossRef]

99. Buckley, R. Environmental inputs and outputs in ecotourism: Geotourism with a positive triple bottom line? J. Ecotourism 2003, 2, 76-82. [CrossRef]

100. Farsani, N.T.; Coelho, C.O.A.; Costa, C.M.M.; Amrikazemi, A. Geo-knowledge Management and Geoconservation via Geoparks and Geotourism. Geoheritage 2014, 6, 185-192. [CrossRef]

101. Henriques, M.H.; dos Reis, R.P.; Brilha, J.; Mota, T. Geoconservation as an emerging geoscience. Geoheritage 2011, 3, 117-128. [CrossRef]

102. Hose, T.A. 3G's for Modern Geotourism. Geoheritage 2012, 4, 7-24. [CrossRef] 
103. Hose, T.A. Towards a history of geotourism: Definitions, antecedents and the future. Geol. Soc. Spec. Publ. 2008, 300, 37-60. [CrossRef]

104. Newsome, D.; Dowling, R.; Leung, Y.F. The nature and management of geotourism: A case study of two established iconic geotourism destinations. Tour. Manag. Perspect. 2012, 2-3, 19-27. [CrossRef]

105. Vasiljević, D.A.; Marković, S.B.; Hose, T.A.; Smalley, I.; Basarin, B.; Lazić, L.; Jović, G. The Introduction to Geoconservation of loess-palaeosol sequences in the Vojvodina region: Significant geoheritage of Serbia. Quat. Int. 2011, 240, 108-116. [CrossRef]

106. Page, K. Geoheritage. Available online: https://www.springer.com/journal/12371 (accessed on 7 September 2020).

107. Joyce, E.B. Australia's Geoheritage: History of Study, A New Inventory of Geosites and Applications to Geotourism and Geoparks. Geoheritage 2010, 2, 39-56. [CrossRef]

108. Booth, K.A.; Brayson, J. Geology, landscape and human interactions: Examples from the Isle of Wight. Proc. Geol. Assoc. 2011, 122, 938-948. [CrossRef]

109. Ollier, C. Problems of geotourism and geodiversity. Quaest. Geogr. 2012, 31, 57-61. [CrossRef]

110. Reynard, E.; Coratza, P. Scientific research on geomorphosites. A review of the activities of the IAG working group on geomorphosites over the last twelve years. Geogr. Fis. e Din. Quat. 2013, 36, 159-168. [CrossRef]

111. Badiali, F.; Ilieş, D.C.; Castaldini, D. A tale of a city, through its urban landscape and cultural heritage in the heart of Europe: The case study of Oradea city (Romania). Geoj. Tour. Geosites 2018, 21, 88-102.

112. Borghi, A.; d'Atri, A.; Martire, L.; Castelli, D.; Costa, E.; Dino, G.; Favero Longo, S.E.; Ferrando, S.; Gallo, L.M.; Giardino, M.; et al. Fragments of the Western Alpine Chain as Historic Ornamental Stones in Turin (Italy): Enhancement of Urban Geological Heritage through Geotourism. Geoheritage 2014, 6, 41-55. [CrossRef]

113. Szepesi, J.; Harangi, S.; Ésik, Z.; Novák, T.J.; Lukács, R.; Soós, I. Volcanic Geoheritage and Geotourism Perspectives in Hungary: A Case of an UNESCO World Heritage Site, Tokaj Wine Region Historic Cultural Landscape, Hungary. Geoheritage 2017, 9, 329-349. [CrossRef]

114. Hou, J.; Yang, X.; Chen, C. Emerging trends and new developments in information science: A document co-citation analysis (2009-2016). Scientometrics 2018, 115, 869-892. [CrossRef]

115. Reynard, E.; Perret, A.; Bussard, J.; Grangier, L.; Martin, S. Integrated Approach for the Inventory and Management of Geomorphological Heritage at the Regional Scale. Geoheritage 2016, 8, 43-60. [CrossRef]

116. Coratza, P.; Giusti, C. Methodological proposal for the assessment of the scientific quality of geomorphosites. Alp. Mediterr. Quat. 2005, 18, 307-313.

117. Pereira, P.; Pereira, D.; Caetano Alves, M.I. Geomorphosite assessment in Montesinho Natural Park (Portugal). Geogr. Helv. 2007, 62, 159-168. [CrossRef]

118. Panizza, M. Geomorphosites: Concepts, methods and examples of geomorphological survey. Chinese Sci. Bull. 2001, 46, 4-6. [CrossRef]

119. Panizza, M.; Piacente, S. Cultural geomorphology and geodiversity. In Geomorphosites; Reynard, E., Paola Coratza, G.R.-B., Eds.; Verlag Dr. Friedrich Pfeil: München, Germany, 2009; pp. 35-48, ISBN 9783899370942.

120. Panizza, M.; Piacente, S. Geomorfologia Culturale; Pitagora Editrice: Bologna, Italy, 2003.

121. Brilha, J. Inventory and Quantitative assessment of Geosites and Geodiversity Sites: A Review. Geoheritage 2016, 8, 119-134. [CrossRef]

122. Ruban, D.A. Quantification of geodiversity and its loss. Proc. Geol. Assoc. 2010, 121, 326-333. [CrossRef]

123. Burek, C.V.; Prosser, C.D. The history of geoconservation: An introduction. Geol. Soc. Spec. Publ. 2008, 300, 1-5. [CrossRef]

124. Prosser, C.D.; Bridgland, D.R.; Brown, E.J.; Larwood, J.G. Geoconservation for science and society: Challenges and opportunities. Proc. Geol. Assoc. 2011, 122, 337-342. [CrossRef]

125. Prosser, C.D. Our rich and varied geoconservation portfolio: The foundation for the future. Proc. Geol. Assoc. 2013, 124, 568-580. [CrossRef]

126. Prosser, C.; Murphy, M.; Larwood, J. Geological Conservation: A Guide to Good Practice; Natural England: York, UK, 2006; Volume 144, ISBN 1857169069.

127. Gordon, J.E. Geoheritage, geotourism and the cultural landscape: Enhancing the visitor experience and promoting geoconservation. Geosciences 2018, 8, 136. [CrossRef]

128. Vasiljević, D.A.; Marković, S.B.; Hose, T.A.; Ding, Z.; Guo, Z.; Liu, X.; Smalley, I.; Lukić, T.; Vujičić, M.D. Loess-palaeosol sequences in china and europe: Common values and geoconservation issues. Catena 2014, 117, 108-118. [CrossRef] 
129. Newsome, D.; Dowling, R. The scope and nature of geotourism. In Geotourism; Routledge: London, UK, 2006; pp. 31-53, ISBN 0-7506-6215-9.

130. Mc Keever, P.J.; Zouros, N. Geoparks: Celebrating earth heritage, sustaining local communities. Episodes 2005, 28, 274-278. [CrossRef]

131. Moufti, M.R.; Németh, K. The Intra-Continental Al Madinah Volcanic Field, Western Saudi Arabia: A Proposal to Establish Harrat Al Madinah as the First Volcanic Geopark in the Kingdom of Saudi Arabia. Geoheritage 2013, 5, 185-206. [CrossRef]

132. Erfurt-Cooper, P. Volcanic Tourist Destinations; Erfurt-Cooper, P., Ed.; Geoheritage, Geoparks and Geotourism; Springer: Berlin/Heidelberg, Germany, 2014; ISBN 978-3-642-16190-2.

133. Kereszturi, G.; Nmeth, K. Monogenetic Basaltic Volcanoes: Genetic Classification, Growth, Geomorphology and Degradation. Updat. Volcanol. New Adv. Underst. Volcan. Syst. 2012, 16-17. [CrossRef]

134. Zangmo, G.T.; Kagou, A.D.; Nkouathio, D.G.; Gountié, M.D.; Kamgang, P. The Volcanic Geoheritage of the Mount Bamenda Calderas (Cameroon Line): Assessment for Geotouristic and Geoeducational Purposes. Geoheritage 2017, 9, 255-278. [CrossRef]

135. Zangmo Tefogoum, G.; Kagou Dongmo, A.; Nkouathio, D.G.; Wandji, P.; Gountié Dedzo, M. Geomorphological features of the Manengouba Volcano (Cameroon Line): Assets for potential geopark development. Geoheritage 2014, 6, 225-239. [CrossRef]

136. Wimbledon, W.A.P.; Ishchenko, A.A.; Gerasimenko, N.P.; Karis, L.O.; Suominen, V.; Johansson, C.E.; Freden, C. Geosites-an IUGS initiative: Science supported by conservation. In Geological Heritage: Its Conservation and Management; IGME: Madrid, Spain, 2000; pp. 69-94.

137. Wimbledon, W.A.; Smith-Meyer, S. Geoheritage in Europe and Its Conservation; ProGEO: Uppsala, Sweden, 2012; Volume 405, ISBN 978-82-426-2476-5.

138. Doyle, P.; Robinson, E. The Victorian 'Geological Illustrations' of Crystal Palace Park. Proc. Geol. Assoc. 1993, 104, 181-194. [CrossRef]

139. Robinson, E. Tourism in geological landscapes. Geol. Today 1998, 14, 151-153. [CrossRef]

140. Mansur, K.L.; da Silva, A.S. Society's Response: Assessment of the Performance of the "Caminhos Geológicos" ("Geological Paths") Project, State of Rio de Janeiro, Brazil. Geoheritage 2011, 3, 27-39. [CrossRef]

141. Kubalíková, L. Geomorphosite assessment for geotourism purposes. Czech J. Tour. 2014, 2, 80-104. [CrossRef]

142. Warowna, J.; Migoń, P.; Kołodyńska-Gawrysiak, R.; Kiebała, A.; Zgłobicki, W. Geomorphosites of Poland-The role played by the Central Register of Geosites. Landf. Anal. 2013, 22, 117-124. [CrossRef]

143. Johnson, M. Best Practices. Tribol. Lubr. Technol. 2010, 66, 18-23.

144. Kubalíková, L.; Kirchner, K. Geosite and Geomorphosite Assessment as a Tool for Geoconservation and Geotourism Purposes: A Case Study from Vizovická vrchovina Highland (Eastern Part of the Czech Republic). Geoheritage 2016, 8, 5-14. [CrossRef]

145. Štrba, L.; Rybár, P.; Baláž, B.; Molokáč, M.; Hvizdák, L.; Kršák, B.; Lukáč, M.; Muchová, L.; Tometzová, D.; Ferenčíková, J. Geosite assessments: Comparison of methods and results. Curr. Issues Tour. 2015, 18, 496-510. [CrossRef]

146. Štrba, L'. Identification and evaluation of geosites along existing tourist trail as a primary step of geotourism development: Case study from the Spiš region (Slovakia). Geoj. Tour. Geosites 2015, 16, 126-140.

147. Martinez-Graña, A.M.; Goy, J.L.; Cimarra, C. 2D to 3D geologic mapping transformation using virtual globes and flight simulators and their applications in the analysis of geodiversity in natural areas. Environ. Earth Sci. 2015, 73, 8023-8034. [CrossRef]

148. Martínez-Graña, A.M.; Goy, J.L.; Cimarra, C.A. A virtual tour of geological heritage: Valourising geodiversity using google earth and QR code. Comput. Geosci. 2013, 61, 83-93. [CrossRef]

149. Mampel, L.; Cobos, A.; Alcalá, L.; Luque, L.; Royo-Torres, R. An Integrated System of Heritage Management Applied to Dinosaur Sites in Teruel (Aragón, Spain). Geoheritage 2009, 1, 53-73. [CrossRef]

150. García-Cortés, A.; Carcavilla, L.; Díaz-Martínez, E.; Vegas, J. Documento metodológico para la elaboración del inventario español de lugares de interés geológico (IELIG). Inst. Geológico y Min. España 2009, $12,61$.

151. Pieri, P.; Sabato, L.; Tropeano, M. Significato geodinamico dei caratteri deposizionali e strutturali della Fossa Bradanica nel Pleistocene. Mem. Della Soc. Geol. Ital. 1996, 51, 501-515.

152. Sabato, L.; Tropeano, M.; Festa, V.; Longhitano, S.G.; dell'Olio, M. Following Writings and Paintings by Carlo Levi to Promote Geology Within the "Matera-Basilicata 2019, European Capital of Culture" Events (Matera, Grassano, Aliano-Southern Italy). Geoheritage 2019, 11, 329-346. [CrossRef] 
153. Beneduce, P.; Festa, V.; Francioso, R.; Schiattarella, M.; Tropeano, M. Conflicting drainage patterns in the Matera Horst Area, southern Italy. Phys. Chem. Earth 2004, 29, 717-724. [CrossRef]

154. Bentivenga, M.; Palladino, G. II patrimonio geologico dell'Alta Val d'Agri (Basilicata sud-occidentale). In Proceedings of the Conference paper $1^{\circ}$ Congresso dell'Ordine dei Geologi di Basilicata, "Ricerca, Sviluppo ed Utilizzo delle Fonti Fossili: Il Ruolo del Geologo", Potenza, Italy, 7 September 2012; pp. 365-385.

155. Bentivenga, M.; Palladino, G.; Prosser, G.; Guglielmi, P.; Geremia, F.; Laviano, A. A Geological Itinerary Through the Southern Apennine Thrust Belt (Basilicata-Southern Italy). Geoheritage 2017, 9. [CrossRef]

156. Francesco, G.; Mario, B.; Giuseppe, P. Environmental geology applied to geoconservation in the interaction between geosites and linear infrastructures in South-Eastern Italy. Geoheritage 2015, 7, 33-46. [CrossRef]

157. Filocamo, F.; Rosskopf, C.M.; Amato, V.; Cesarano, M.; Di Paola, G. The integrated exploitation of the geological heritage: A proposal of geotourist itineraries in the Alto Molise area (Italy). Rend. Online Soc. Geol. Ital. 2015, 33, 44-47. [CrossRef]

158. Aucelli, P.P.C.; Cesarano, M.; Di Paola, G.; Filocamo, F.; Rosskopf, C.M. Geomorphological map of the central sector of the Matese Mountains (Southern Italy): An example of complex landscape evolution in a Mediterranean mountain environment. J. Maps 2013, 9, 604-616. [CrossRef]

159. Lamich, D.; Marschalko, M.; Yilmaz, I.; Bednářová, P.; Niemiec, D.; Durd'ák, J.; Kubečka, K.; Duda, R. Utilization of engineering geology in geo-tourism: Few case studies of subsidence influence on historical churches in Ostrava-Karvina District (Czech Republic). Environ. Earth Sci. 2016, 75, 1-12. [CrossRef]

160. Marschalko, M.; Duraj, M.; Niemiec, D.; Yilmaz, I.; Pryvalov, A. Churches Influenced by Underground Mining in the Karvina Region Used for the Purposes of Geotourism. Procedia Eng. 2016, 161, 2271-2275. [CrossRef]

161. Marschalko, M.; Yilmaz, I.; Bednárik, M.; Kubečka, K. Deformation of slopes as a cause of underground mining activities: Three case studies from Ostrava-Karviná coal field (Czech Republic). Environ. Monit. Assess. 2012, 184, 6709-6733. [CrossRef] [PubMed]

(C) 2020 by the authors. Licensee MDPI, Basel, Switzerland. This article is an open access article distributed under the terms and conditions of the Creative Commons Attribution (CC BY) license (http://creativecommons.org/licenses/by/4.0/). 